\title{
Simulation of dust aerosol and its regional feedbacks over East Asia using a regional climate model
}

\author{
D. F. Zhang ${ }^{1,2,3}$, A. S. Zakey ${ }^{4}$, X. J. Gao ${ }^{2,4}$, F. Giorgi ${ }^{4}$, and F. Solmon ${ }^{5}$ \\ ${ }^{1}$ LASG, Institute of Atmospheric Physics, Chinese Academy of Sciences, 100029, Beijing, China \\ ${ }^{2}$ National Climate Center, China Meteorological Administration, 100081, Beijing, China \\ ${ }^{3}$ Graduate University of Chinese Academy of Sciences, 100049, Beijing, China \\ ${ }^{4}$ Abdus Salam International Centre for Theoretical Physics, 34100, Trieste, Italy \\ ${ }^{5}$ Laboratoire d'Aérologie, 31400, Toulouse, France
}

Received: 11 December 2007 - Published in Atmos. Chem. Phys. Discuss.: 4 March 2008

Revised: 4 December 2008 - Accepted: 5 January 2009 - Published: 16 February 2009

\begin{abstract}
The ICTP regional climate model (RegCM3) coupled with a desert dust aerosol model is used to simulate the net radiative forcing (short-wave and long-wave) and related climate effects of dust aerosols over East Asia. Two sets of experiments are completed and intercompared, one without (Exp. 1) and one with (Exp. 2) the radiative effects of dust aerosols. The experiments encompass the main dust producing months, February through May, for 10 years (1997-2006), and the simulation results are evaluated against ground station and satellite data. The model captures the basic observed climatology over the area of interest. The spatial and temporal variations of near surface concentration, mass load, optical depth and emission of dust aerosols from the main source regions are reproduced by model. The main model deficiency is an overestimate of dust amounts over the source regions and an underestimate downwind of these source areas, which indicates an underestimate of dust dispersal. Over the desert source regions, the net TOA radiative forcing is positive, while it is small over the other regions as a result of high surface albedo values which reduce the shortwave radiative forcing. The net surface radiative fluxes are decreased by dust and this causes a surface cooling locally up to $-1^{\circ} \mathrm{C}$. The inclusion of net (short-wave and long-wave) dust radiative forcing leads to a reduction of dust emission in the East Asia source regions, which is mainly caused by an increase in local stability and a corresponding decrease in dust lifting. Our results indicate that dust effects should be included in the assessment of climate change over East Asia.
\end{abstract}

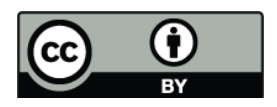

Correspondence to: A. S. Zakey (azakey@ictp.it)

\section{Introduction}

Atmospheric aerosols are still considered one of the main sources of uncertainty within the climate change debate (IPCC, 2007). In particular, increasing attention is being paid to the effect of desert dust aerosols, since dust clouds can affect long- and short-wave radiation and can play an important role in modifying climate at the regional scale (Christopher et al., 2003; Dey et al., 2004). In this regard, it is worth mentioning that no AOGCM used for climate change projections in the IPCC fourth assessment report includes the radiative effects of desert dust.

The direct radiative forcing of desert dust aerosol is thought to be important in modulating global and regional climates. Dust aerosol affects the atmosphere's radiation budget (Tegen et al., 1996; Sokolik et al., 1996) and chemical composition (Dentener et al., 1996; Dickerson et al., 1997; Martin et al., 2003). The broader impacts of the dust cycle have been investigated in studies of Chinese loess/paleoclimate relationships (Zhang, 1984; Porter, 2001) and in the observations of Asian dust storm frequencies for the last century (Natsagdorj et al., 2003; Zhang et al., 2003a, b). The former provide some perspective on the dust-climate interactions that operated before the Earth system became perturbed by human activities.

Due to the uncertainties in the estimates of dust loadings and radiative properties, it is difficult to estimate the dust radiative effects (Sokolik et al., 1996; Myhre et al., 2001; Aoki et al., 2005). On the global scale, estimates of dust emission differ by more than a factor of two (ranging from 1000 to $2150 \mathrm{Tg} \mathrm{yr}^{-1}$ ), while the dust mass load estimates range by a factor of four (8-36 $\mathrm{Tg} \mathrm{yr}^{-1}$ ) (Zender et al., 2004). Since the late 1980s, models for global, regional and local dust simulation have been developed. Early attempts of dust modeling were made by Westphal et al. (1988), Gillette et al. (1989),

Published by Copernicus Publications on behalf of the European Geosciences Union. 
Table 1. Distribution of dust source regions.

\begin{tabular}{lcrr}
\hline Name & Lat $\left({ }^{\circ} \mathrm{N}\right)$ & Lon $\left({ }^{\circ} \mathrm{E}\right)$ & Area $\left(\mathrm{km}^{2}\right)$ \\
\hline Taklimakan & 39.0 & 83.0 & 337600 \\
Gurbantunggut & 45.1 & 87.3 & 48800 \\
Kumtag & 39.7 & 92.0 & 22900 \\
Badain Jaran & 40.4 & 102.0 & 44300 \\
Tengger & 38.0 & 104.2 & 42700 \\
Ulan Buh & 40.4 & 106.5 & 9900 \\
Hobq & 40.5 & 107.9 & 16100 \\
Mu Us & 38.8 & 109.1 & 32100 \\
Onqin Daga & 43.0 & 115.0 & 21400 \\
Horqin & 43.3 & 122.0 & 42300 \\
\hline
\end{tabular}

and Joussaume (1990). Examples of global dust models include the studies of Tegen et al. (1994), Ginoux et al. (2004), Zender et al. (2003) and Tanaka et al. (2003). Examples of regional studies include Shao et al. (1997), Nickovic et al. (2001), Gong et al. (2003), Liu et al. (2003), and Zakey et al. (2006), while regional climatological characteristics of dust phenomena have been described in some observational studies (Pye, 1987; Goudie et al., 1992).

East Asia is one of the most prominent regions of dust generation. Asian dust source regions include the Gobi desert and the highlands of Northwestern China (Zhang et al., 2003a). Over East Asia, estimation of dust aerosols is particularly difficult due to complex topography, land-use, and snow cover features. In fact, dust concentrations over East Asia tend to be systematically underestimated by global models (Tegen et al., 2002; Luo et al., 2003).

Observational evidence suggests that dust originating from East Asia has a significant influence even at the global scale. For example, it is reported that East Asian dust can be transported to wide areas of the Pacific Ocean (Husar et al., 2001), reaching as far as North America (McKendry et al., 2001). Deposits of Asian dust have been identified from snow samples in Greenland (Biscaye et al., 1997; Bory et al., 2003) and even in the French Alps (Grousset et al., 2003).

Dust storms over East Asia occur primarily in spring (March-May), when strong winds entrain large quantities of dust particles into the atmosphere and carry them downstream (Zhang, 2001; Shao et al., 2006). Extremely severe dust storms in the past have resulted in the loss of human lives and the disruption of economic activities (Cheng et al., 1996). In fact, dust storms are widely recognized as a serious environmental problem in East Asia and have attracted much scientific attention. In China, arid and semiarid areas occupy 3.57 million $\mathrm{km}^{2}$ (Shao et al., 2006). The desert distribution from west to east is shown in Table 1. These deserts, as well as the Gobi in Mongolia, are the main sources of East Asia dust storms (Qin, 2002).
The climatology of dust storms in China is quite well documented through the analysis of synoptic records over the past 50 years (Zhou, 2001; Chun et al., 2001; Kurosaki et al., 2003; Shao et al., 2003) and satellite data in more recent years (Prospero et al., 2002). The number of dust storm occurrences during the period 1954-2002 shows that, with respect to the annual total, the percentage of the occurrence of severe dust episodes is $6.3 \%$ in February, $18.4 \%$ in March, $44.4 \%$ in April, and $19.7 \%$ in May (Zhou et al., 2003). A decreasing trend of severe dust storm occurrence has been observed in recent decades due to a decrease in wind speed over the source regions (Zhou, 2001; Zhou et al., 2003). The maximum storm occurrence is found in the 1950s, followed by a continuous decrease until the 1990s and a slight increase since 2000 (Zhou et al., 2003). According to synoptic records over the past 50 years, 2000, 2001 and 2002 are among the most active years in terms of severe dust storm occurrence over East Asia (Zhang et al., 2002).

From these considerations it is clear that desert dust aerosol is a major element of the environment of East Asia, and might thus be an important component of climate change over the region. In order to study the effects of dust on regional climate, Zakey et al. (2006) developed a radiatively active desert dust module and coupled it to a regional climate model (the ICTP RegCM3; Pal et al., 2007). We here use this coupled modeling system to provide a preliminary study of the potential dust effects on the present climate of East Asia. It is noted that former simulations of dust storms over the region mostly focused on individual case studies in which the dust was not radiatively coupled with the meteorological models (Zhang et al., 2003a, b; Zhao et al., 2006b). Therefore, this is the first regional model based long term simulation of dust radiative effects over East Asia.

The primary purpose of the present study is to present a first evaluation of our modeling system over this region, going from dust emission and burden to dust radiative effects and regional climatic response. In this regard, one important caveat should be highlighted: we do not include the interaction of dust with the cloud microphysics and hence we focus on direct and semi-direct effects. The development of parameterizations of this process is currently under way and its implementation and testing within our modeling system is left to future work. Note that, compared to the work of $\mathrm{Za}$ key et al. (2006) our simulations also include the long-wave radiative forcing.

In Sect. 2 we first describe the model and experiment design, while in Sect. 3 we discuss the model results for the area of study. In particular, we analyze surface emission, near surface concentrations, dry and wet deposition processes, aerosol optical properties, and the short and long-wave radiative forcing. Our concluding considerations and perspectives for future work are presented in Sect. 4. 


\section{Model, data and experiment design}

The model employed in the present study is the Regional Climate Model RegCM version 3 (RegCM3) developed at the Abdus Salam International Centre for Theoretical Physics (ICTP) (Pal et al., 2007). RegCM3 is an evolution from the version of Giorgi et al. (1993a, b), with improvements in various physics packages (Pal et al., 2007). The solar (SW) and atmospheric (LW) radiation schemes are described in Kiehl et al. (1996). Land surface processes are represented via the Biosphere-Atmosphere Transfer Scheme (BATS1e; Dickinson et al., 1993), while planetary boundary layer computations employ the non-local formulation of Holtslag et al. (1990). The mass flux scheme of Grell (1993) is used to describe convective precipitation and the sub-grid explicit moisture scheme of Pal et al. (2000) is used to describe nonconvective precipitation.

\subsection{Dust scheme}

An on-line dust scheme is interactively coupled to the RegCM, accounting for emission, transport and deposition of four particle size-bins (Zakey et al., 2006). Transport processes are described by the tracer transport equation of Solmon et al. (2006) and Zakey et al. (2006), which includes advection by resolvable scale winds, transport by turbulence and deep convection, gravitational settling, wet and dry removal processes. Wet deposition is treated following Giorgi (1989) for large-scale precipitation and Giorgi et al. (1986) for convective precipitation. The gravitational settling and dry deposition terms are described by Zakey et al. (2006).

The dust emission scheme is based on Marticorena et al. (1995) and Alfaro et al. (2001). It comprises three components (Zakey et al., 2006): (1) the threshold friction velocity at which wind erosion is initiated, (2) the horizontal and vertical dust emission flux and (3) the surface and soilrelated factors influencing either the threshold friction velocity or the dust fluxes, including soil water content, soil texture type, vegetation cover, and snow cover. In this regard, dust is emitted only from the vegetation-free and snow-free portion of the grid box, which are calculated by the BATS scheme (Dickinson et al., 1993). The dust module has a size spectrum of 0.01 to $20.0 \mu \mathrm{m}$, which is divided into 4 size-bins, each covering part of the whole spectrum of particle diameter: i.e. the fine $(0.01-1.0 \mu \mathrm{m})$, accumulation $(1.0-2.5 \mu \mathrm{m})$, coarse $(2.5-5.0 \mu \mathrm{m})$, and giant $(5.0-20.0 \mu \mathrm{m})$ particle mode. The evolution of each bin is described by a prognostic equation for the dry size of the dust particle (Zakey et al., 2006). Note that the scheme has capability of dividing the size spectrum into a larger number of bins, but 4 were chosen for describing all main particle size modes in a computational efficient way.

The radiative code in the RegCM employs the $\delta$-Eddington approximation for radiative flux calculations, and the wavelength spectrum is divided into 18 discrete intervals from
0.2 to $4.5 \mu \mathrm{m}$. Seven of these span the ultraviolet $(0.2$ to $0.35 \mu \mathrm{m})$, and one covers the visible $(0.35$ to $0.7 \mu \mathrm{m})$.The dust SW radiative effect is calculated using asymmetry factor $(g)$, single scattering albedo $(\omega)$, and mass extinction coefficient $\left(k_{\text {ext }}\right)$ obtained from Mie calculations. The refractive indices of mineral dust aerosols for the relevant SW spectral windows are taken from the OPAC database (Hess et al., 1998).

In the LW domain, dust effects are accounted for by introducing the dust emissivity (and hence absorptivity) according to the parametrization of Kiehl et al. (1996). The dust LW emissivity is calculated according to:

$\varepsilon_{l w}(z)=1-e^{-D \cdot k_{\text {lwabs }} \cdot b(z)}$

where $D=1.66$ is a diffusivity factor, $b(z)$ is the dust burden $\left(\mathrm{g} \mathrm{m}^{-2}\right)$ of a given layer and $k_{\text {lwabs }}\left(\mathrm{m}^{2} \mathrm{~g}^{-1}\right)$ is the mass absorption coefficient calculated using Mie theory for the relevant LW spectral windows, for each size bin and using LW refractive indices consistent with Wang et al. (2006).

The OPAC dataset allows the calculation of dust optical properties at 61 wavelengths between 0.25 and $40 \mu \mathrm{m}$, providing the real and imaginary parts of the refractive indices for each wavelength. In our study we use the wavelength range from 0.2 to $4.5 \mu \mathrm{m}$. It has been shown that the parameter best related to the radiative properties of a given size distribution is the cross section weighted effective radius " $r e$ " which is defined as:

$r_{e}=\frac{\int_{r_{\text {lower }}}^{r_{\text {upper }}} n(r)[r]^{3} d r}{\int_{r_{\text {lower }}}^{r_{\text {upper }}} n(r)[r]^{2} d r}$

where " $r$ " is the dry dust aerosol radius at $0 \%$ relative humidity RH and $n(r)$ is the number distribution of dry dust particles. The general relationship between the aerosol extinction optical depth " $\tau$ " and the aerosol mass loading per unit area " $M$ " can be expressed as:

$\tau=\frac{3 Q M}{4 \rho_{d} r_{e}}$

where $\rho_{d}$ is the dust aerosol density, $r_{e}$ is the effective radius, and $Q$ is the extinction coefficient, which is taken from Mie calculations using the OPAC refractive indices at different wavelength. Both $\tau$ and $Q$ are wavelength-dependent. The most convenient way of linking the aerosol optical depth with the aerosol dry mass " $m_{d}$ " is $\tau=\beta m_{d}$, where $\beta$ is the specific extinction or mass extinction efficiency $\left(\mathrm{m}^{2} \mathrm{~g}^{-1}\right)$, defined as,

$\beta=\frac{3 Q M}{4 \rho_{d} r_{e} m_{d}}$

In our aerosol radiative forcing calculations we use these eight wavelength bands and in order to reduce the computational cost we only calculate parameters for the mid-band $(0.35-0.7 \mu \mathrm{m})$ wavelength. 


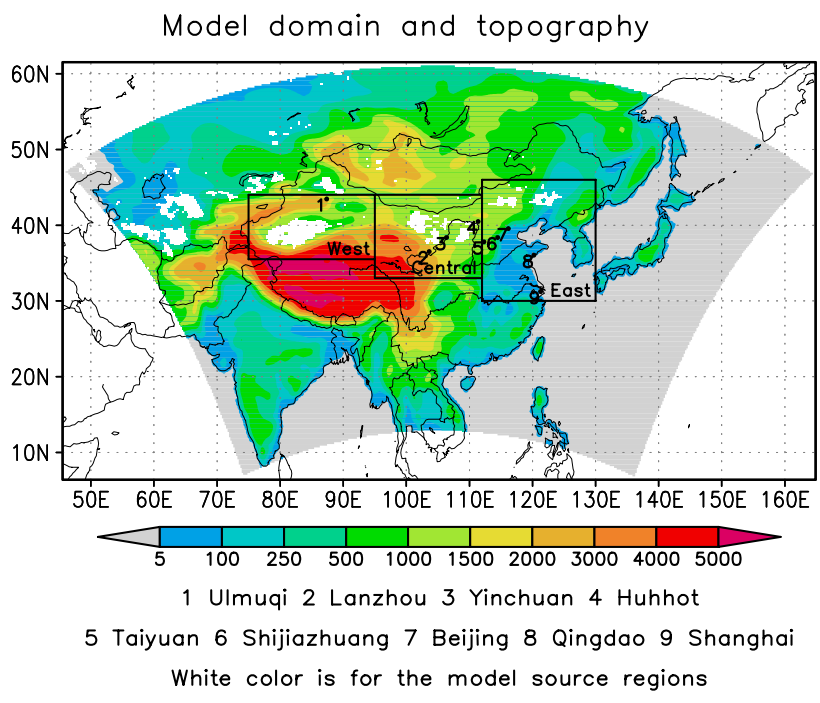

Fig. 1. Model domain and topography. Units are meters. Also shown are the three China source regions and the location of nine stations selected for model validation.

The dust radiative forcing occurs at the surface and within the atmosphere and can trigger some differential warming/cooling effects and thus contrasting climatic responses. Dust radiative forcing occurs in the short wave (SW or solar) and long wave (LW or thermal) spectral regions and depends on the surface albedo, the presence of clouds and the dust spatial distribution, optical properties and size distribution (Liao and Seinfeld, 1998). We note that the dust optical properties depend on many factors, such as dust particle size distribution, shape and absorbing/diffusive properties which are extremely variable and hence very difficult to represent accurately in climate models (Balkanski et al., 2007). Values of single scattering albedo of dust aerosols used in the literature exhibit a great variability.

The dust aerosol index DI is calculated as in Ginoux et al. (2003). The radiation module in RegCM has a visible range with lower limit at $0.35 \mu \mathrm{m}$ and upper limit at $0.7 \mu \mathrm{m}$ and within this range we assume that the DI does not have large fluctuations when calculated for $500 \mathrm{~nm}$ (as in our case) instead of $380 \mathrm{~nm}$ (Ginoux et al., 2003). The DI is defined as

$\mathrm{DI}=\left\{1-0.2 \log \left(P_{S}\right)\right\}\left[1.25+5\left(1-\omega_{\lambda}\right) h\right]\left(\tau_{\lambda}\right)^{\omega_{\lambda}}$

where $P s$ is the surface pressure, $\omega_{\lambda}$ is the single scattering albedo, $h$ is the depth of the aerosol layer (scale height of dust particles, in $\mathrm{km}), \tau_{\lambda}$ is the optical depth at $\lambda=380 \mathrm{~nm}$, which we assume to have the same value as that at $\lambda=500 \mathrm{~nm}$. We use the $500 \mathrm{~nm}$ wavelength because this is the most effective wavelength in the short-wave spectrum and in order to compare with the satellite data (see below).

\subsection{Experiment design}

In our simulation the following data sets are used: 1) Meteorological initial and time-evolving lateral boundary conditions for the RegCM simulations are from the National Center for Environmental Prediction/National Center for Atmospheric Research (NECP) re-analysis (Kalnay et al., 1996); 2) Land use types are based on observed data within China (Hou, 1982) and satellite GLCC data developed by the USGS outside China (Loveland et al., 2000); 3) Soil texture data are based on the USDA texture classification (USDA, 1999), with some modifications in central and Northeast China for extra dust sources (Tengger, Onqin Daga, and Horqin) following Zhao et al. (2006b). The model domain encompasses the whole continental China and adjacent areas (see Fig. 1) at a horizontal grid spacing of $50 \mathrm{~km}$. It includes the primary dust producing regions in China. The model is run at its standard configuration of 18 vertical sigma layers and model top at $100 \mathrm{hPa}$. Within the domain we identify three regions for more specific analysis (Fig. 1): 1) West $\left(35.5^{\circ}-44^{\circ} \mathrm{N}\right.$, $\left.\left.75^{\circ}-95^{\circ} \mathrm{E}\right), 2\right)$ Central $\left(33^{\circ}-44^{\circ} \mathrm{N}, 95^{\circ}-112^{\circ} \mathrm{E}\right)$, and 3 ) East $\left(30^{\circ}-46^{\circ} \mathrm{N}, 112^{\circ}-130^{\circ} \mathrm{E}\right)$. Observed data from nine stations are used for the validation of the dust module (Fig. 1).

Each model simulation extends from 1 November to 1 June of the following year. In this way the model can generate its seasonality of snow cover before our analysis period, which is February-March-April-May (FMAM), when most dust storms occur over the region. We simulated 10 years, from 1997 to 2006 and for each of these year two sets of experiments are conducted. The first (Exp. 1) includes the dust model calculations, but the dust is not radiatively active, i.e. the dust climate feedback is not accounted for. In the second set (Exp. 2), all the conditions are the same as in Exp. 1, but the dust is radiatively interactive, which allows us to capture dust-climate feedbacks.

\section{Results and discussion}

In this section we first present an evaluation of the model climatology and dust simulation (for the Exp. 1 case) and then an analysis of the effects of the dust radiative forcing.

\subsection{Climatic features of the region}

Simulation and basic understanding of the regional climatology of East Asia are important for the evaluation of dustinduced climate feedbacks. The climate of East Asia shows a marked seasonality. Winter climate is characterized by dry and cold conditions caused by the mid-latitude westerly jet, which sweeps across the region from the continental interior carrying predominant dry and cold air over China. The summer season is dominated by the onset and development of the East Asia monsoon. As a result of the northward and westward evolution of the western subtropical Pacific High, 
Table 2. Information for the selected nine stations.

\begin{tabular}{lrrr}
\hline Name & Lat $\left({ }^{\circ} \mathrm{N}\right)$ & Lon $\left({ }^{\circ} \mathrm{E}\right)$ & Height $(\mathrm{m})$ \\
\hline Ulmuqi & 43.43 & 87.38 & 918.7 \\
Lanzhou & 36.52 & 103.62 & 1518.3 \\
Yinchuan & 38.37 & 106.37 & 1112.7 \\
Huhhot & 40.49 & 111.37 & 1065.0 \\
Taiyuan & 37.80 & 112.30 & 776.6 \\
Shijiazhuang & 38.05 & 114.48 & 81.2 \\
Beijing & 39.56 & 116.17 & 32.0 \\
Qingdao & 36.04 & 120.22 & 77.2 \\
Shanghai & 31.24 & 121.28 & 8.2 \\
\hline
\end{tabular}

moist southwesterly monsoon flow dominates over the region, inducing warm and wet conditions. Spring, our season of interest, is a transition period between these two climate regimes.

Mean geopotential height and wind fields for FMAM at $850 \mathrm{hPa}$ from the NCEP reanalysis and model simulation are shown in Fig. 2a and b, respectively. A deep trough (the East Asia Trough) over the northeastern coastal region can be found in the re-analysis data (Fig. 2a). This brings cold and dry continental air from high latitudes to North and Northeast China. Conversely, Southeast China is dominated by southerly winds and it is affected by sub-tropical systems occurring in correspondence of the pre-onset stage of the monsoon. The model simulates the East Asia Trough, although this appears to be somewhat deeper than in the re-analysis and leads to an overestimate of northwesterly winds over North and Northeast China (Fig. 2b).

Figure 2c shows FMAM observed precipitation from the Climate Research Unit, (CRU) of the University of East Anglia (Mitchell et al., 2005) averaged over the period 1997-2002 (later years were not available). This precipitation is characterized by maxima over Southeast China and a decrease towards the north and northwest. Less than $0.5 \mathrm{~mm} \mathrm{day}^{-1}$ precipitation is found over Northwest China, which is an arid and semi-arid area where the main sources of dust production are located. The model reproduces this basic precipitation pattern (Fig. 2d), however, a general overestimate of precipitation is found over North and Northwestern China and an underestimate over Southeast China. The largest overestimate can be found in areas of complex topography, e.g. over the eastern edge of the Tibetan Plateau (near $112^{\circ} \mathrm{E}, 32^{\circ} \mathrm{N}$ ). However this may be related to insufficient observations and no gauge under catch and topographical corrections of the data.

The simulated surface air temperature shows a generally good agreement with observations as shown in Fig. 2e and $\mathrm{f}$, with a cold bias of a few ${ }^{\circ} \mathrm{C}$ or less over Central and South China. The model also shows a slight warm bias over Northeast China. Overall, the model reproduces the basic clima-

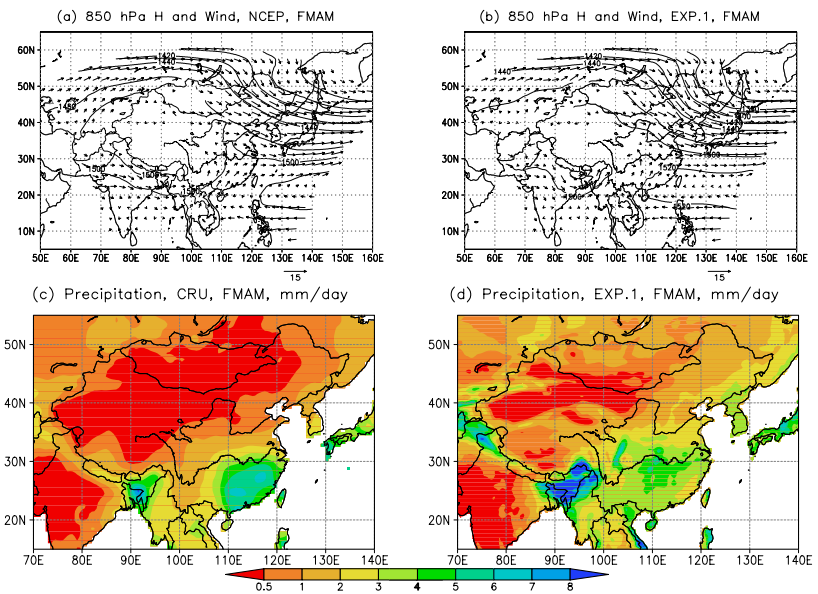

(e) Temperature, CRU, FMAM, ${ }^{\circ} \mathrm{C}$

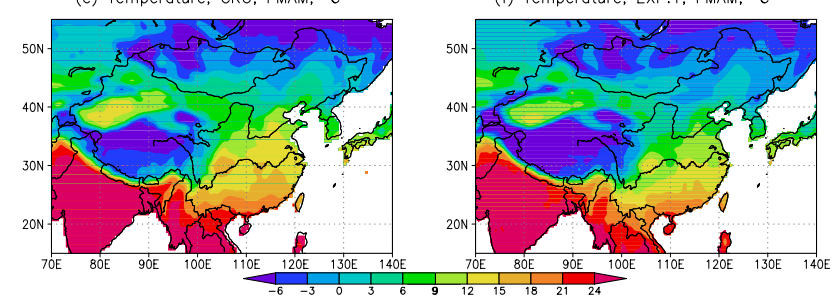

Fig. 2. Mean (1997-2006) $850 \mathrm{hPa}$ height (contour line) and wind (arrows) in FMAM from the NCEP reanalysis (a) and model simulation (Exp. 1) (b); observed (c, 1997-2002, available data), and simulated (d, 1997-2006) mean precipitation; observed (e, 19972002, available data), and simulated (f, 1997-2006) mean temperature. Units are meters for height, $\mathrm{m} \mathrm{s}^{-1}$ for wind, $\mathrm{mm} \mathrm{day}^{-1}$ for precipitation, ${ }^{\circ} \mathrm{C}$ for temperature.

tology over the region of interest and shows a performance in line with that found in previous analysis-driven simulations over this region (Zhang et al., 2007).

\subsection{Dust concentration, mass load, emission and removal}

The simulated annual average near surface dust concentration at the lowest model level is compared with the equivalent $\mathrm{PM}_{10}$ concentration extracted from the Air Quality Index (AQI) (http://www.zhb.gov.cn/quality/air_s.php3) over China for the period 2001-2006 (available data) in Fig. 3. The AQI is a function of $\mathrm{PM}_{10}$ and it is defined by:

$\mathrm{AQI}=\left(I_{\max }-I_{\min }\right) \frac{\left(C-C_{\min }\right)}{\left(C_{\max }-C_{\min }\right)}+I_{\min }$

where $C$ is the concentration of $\mathrm{PM}_{10}, C_{\min }$ and $C_{\max }$ are the minimum and maximum values of $C, I_{\min }$ and $I_{\max }$ are the minimum and maximum values of AQI.

Although the AQI also includes other particulate matter sources, it is still a good indicator of the relative inter-annual variations in dust concentration (Gong et al., 2003). $\mathrm{PM}_{10}$ data from nine stations across China are selected for comparison with the closest model grid point (see Fig. 1 and Table 2). The simulated near-surface dust concentration 

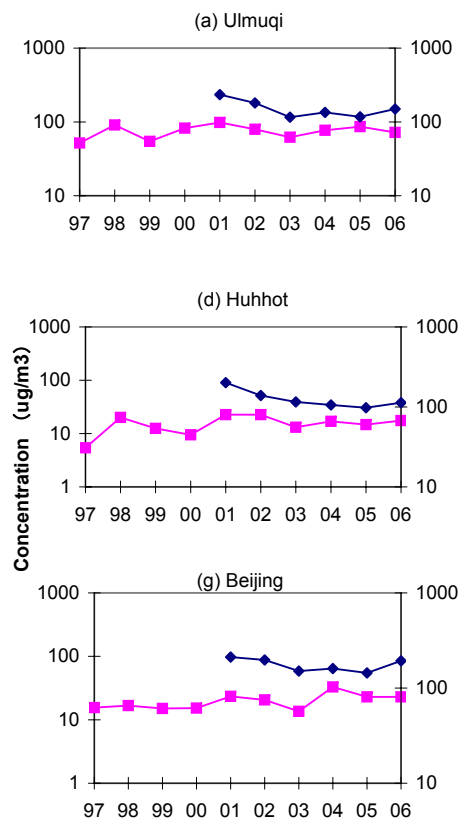

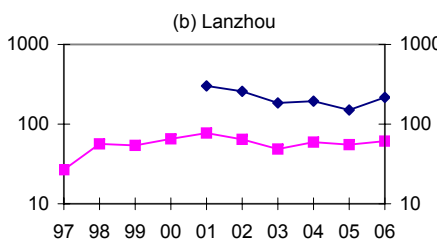

(e) Taiyuan
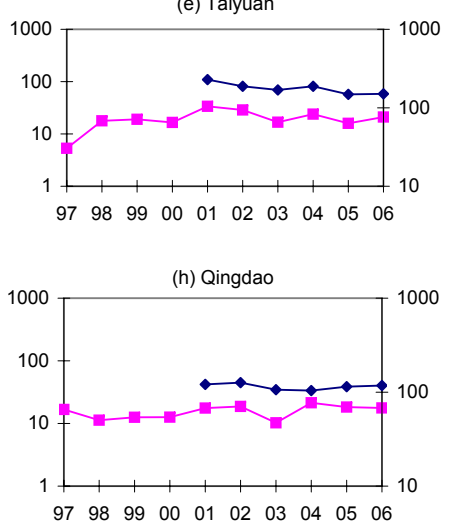
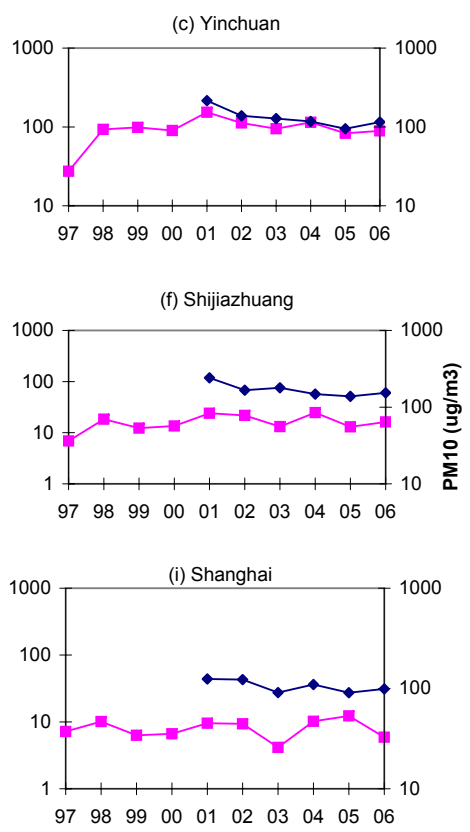

Fig. 3. Observed mean $\mathrm{PM}_{10}$ (derived from the AQI) (2001-2006, available data) and simulated (Exp. 1) near surface dust concentration (1997-2006) in FMAM at the nine observing stations. Units are $\mu \mathrm{g} \mathrm{m}^{-3}$.

(a) mass load $\left(\mathrm{mg} \mathrm{m}^{-2}\right)$

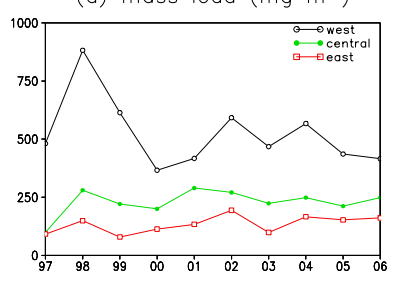

(c) wet deposition ( $\mathrm{mg} \mathrm{m}^{-2}$ day $^{-1}$ )

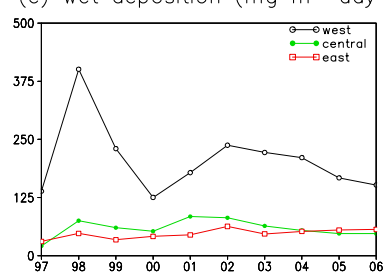

(e) wind speed $\left(\mathrm{m} \mathrm{s}^{-1}\right)$

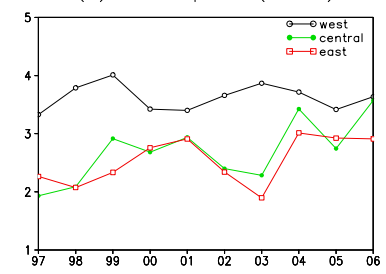

(b) emission ( $\mathrm{mg} \mathrm{m} \mathrm{m}^{-2} \mathrm{day}^{-1}$ )
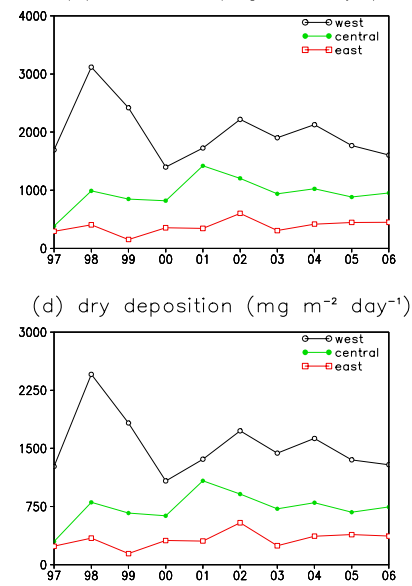

(f) precipitation ( $\left.\mathrm{mm} \mathrm{day}^{-1}\right)$

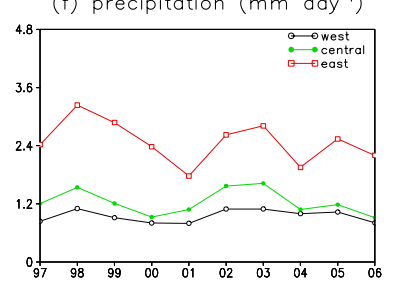

Fig. 4. Simulated (Exp. 1) annual mean (a) mass load, (b) emission, (c) wet deposition, (d) dry deposition, (e) wind speed, (f) precipitation for the three regions (see Fig. 1). Units are $\mathrm{mg} \mathrm{m}^{-2}$ for mass load, $\mathrm{mg} \mathrm{m}^{-2} \mathrm{day}^{-1}$ for emission, wet and dry deposition, $\mathrm{m} \mathrm{s}^{-1}$ for wind, $\mathrm{mm} \mathrm{day}^{-1}$ for precipitation.

$\left(\mu \mathrm{g} \mathrm{m}^{-3}\right)$ and observed $\mathrm{PM}_{10}$ concentration $\left(\mu \mathrm{g} \mathrm{m}^{-3}\right)$ in Fig. 3 are based on two separate vertical axes with log-scales according to Gong et al. (2003). This comparison generally indicates that the model captures the inter-annual variations of near surface concentration at the selected station site, in particular the decrease in concentration between 2001 and 2003.

The inter-annual variation of dust mass load, dust emission, wet and dry deposition, surface wind speed, and precipitation over the three regions of Fig. 1 are shown in Fig. 4. The maximum mass loads, emissions and removal are found over the west region, which contains the largest source areas, with decreasing values over the Central and East regions. The west region also shows the largest interannual fluctuations in mass loading, seemingly related to the fluctuations in wind speed over the extended source areas of the region. Conversely, the East regions show the lowest interannual fluctuations. This is due to the fact that the East region has the smallest dust sources and that the dust mass load there is also strongly derived by transport from upwind larger source areas. Note that precipitation, and thus the efficiency of wet removal are maximum over the East and minimum over the drier West region, while dry deposition, which is mostly associated with wind speed, is maximum over the West region. The mass load, emission, and removal (wet and dry) at the East and Central regions appear highly correlated, likely because one lies downwind of the other and because the dust producing circulations occur at the broad regional scale affecting both regions. 
(a) Ulmuqi $\left(43.4^{\circ} \mathrm{N}, 87.4^{\circ} \mathrm{E}\right)$

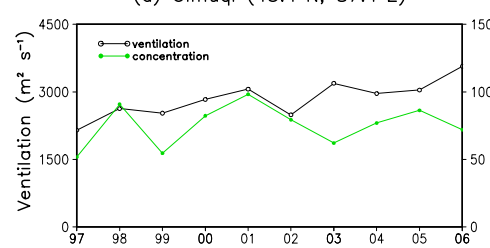

(d) Huhhot $\left(40.5^{\circ} \mathrm{N}, 111.4^{\circ} \mathrm{E}\right)$

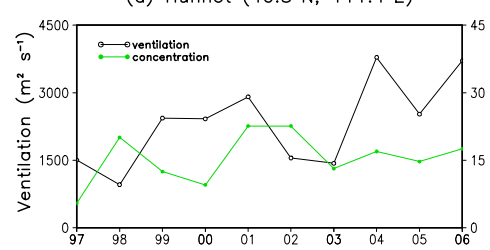

(g) Beijing $\left(39.6^{\circ} \mathrm{N}, 116.2^{\circ} \mathrm{E}\right)$

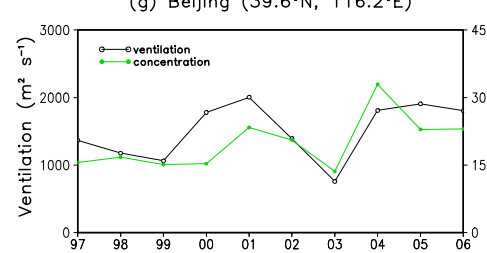

(b) Lanzhou $\left(36.5^{\circ} \mathrm{N}, 103.6^{\circ} \mathrm{E}\right)$

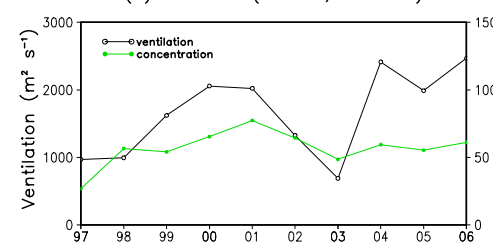

(e) Taiyuan $\left(37.8^{\circ} \mathrm{N}, 112.3^{\circ} \mathrm{E}\right)$

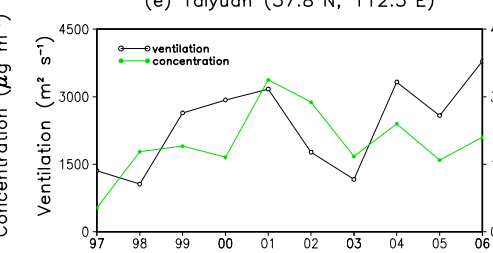

(h) Qingdao $\left(36.0^{\circ} \mathrm{N}, 120.2^{\circ} \mathrm{E}\right)$

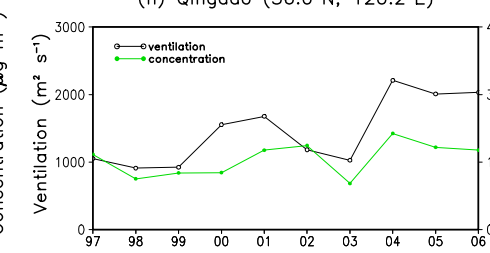

(c) Yinchuan $\left(38.4^{\circ} \mathrm{N}, 106.4^{\circ} \mathrm{E}\right)$

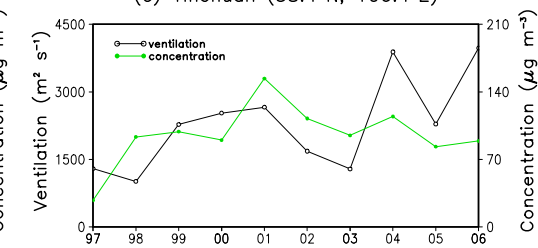

(f) Shijiazhuang $\left(38.1^{\circ} \mathrm{N}, 114.5^{\circ} \mathrm{E}\right)$

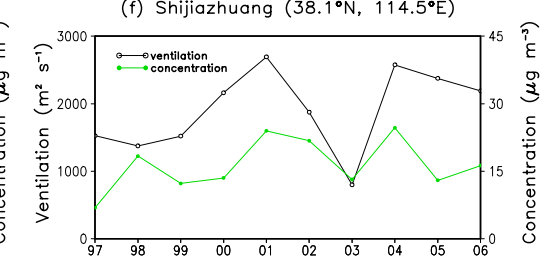

(i) Shanghai $\left(31.2^{\circ} \mathrm{N}, 121.3^{\circ} \mathrm{E}\right)$

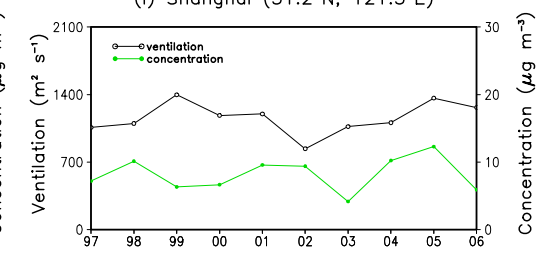

Fig. 5. Simulated (Exp. 1) annual mean ventilation index and dust concentration at the nine station sites. Units are $\mu \mathrm{g} \mathrm{m}{ }^{-3}$ for concentration and $\mathrm{m}^{2} \mathrm{~s}^{-1}$ for the ventilation index.

A further measure of dust dispersion is the ventilation index (VI) (Hsu, 2003; Rao, 2003), which is defined as the product of boundary-layer height and a representative boundary-layer horizontal wind speed. Large values of these two factors imply pronounced vertical and horizontal dust lifting and dispersion. Figure 5 compares the annual average VI and dust concentrations at the 9 selected station sites, showing that variations of VI show similarities to the dust concentrations at these sites. The results indicate that higher VI generally leads to a higher dust concentration in the atmospheric boundary layer, with the exception of 1998. A severe dust storm occurred in April of this year leading to 2-4 times higher near surface dust concentration than any other dust event since 1988 (Husar et al., 2001) and this substantially contributed to the 1998 dust maximum.

\subsection{Optical properties of dust particles}

\subsubsection{Dust aerosol optical depth (AOD)}

Multi-angle Imaging Spectro-radiometer (MISR, 550 nm) satellite (2001-2006, available data ftp://14ftl01.larc.nasa. gov/longterm/MISR/) and simulated multi-year monthly mean AOD (1997-2006) are shown in Fig. 6. The comparison shows that the model captures the areas of maximum dust optical depth in all three regions, with a pronounced maximum over the West region. The model also captures the intra-seasonal evolution of dust amounts, increasing from February to April and then slightly decreasing in May. The extension of the peak AOD values tends to be higher than ob- tained from the MISR estimates, particularly over the West source region. Conversely, the simulated AODs are lower than the MISR values away from the source areas. On the one hand, the model does not describe the presence of additional aerosol types as well as background aerosols, which are present in the MISR data. On the other, however, this may also be an indication of relatively weak long range dispersal of the dust plume by the model.

Most dust dispersal occurs by lifting and detrainment above the boundary layer and subsequent transport by free tropospheric winds. Figure 7 shows a longitude-vertical cross section of dust amount for the latitude band $38-42^{\circ} \mathrm{N}$, which encompasses the main dust source areas, averaged for the 10 simulated years. Although some dust is transported all the way into the Pacific Ocean (up to $150^{\circ} \mathrm{E}$ ), it is evident that most of the dust loads are confined within the lower atmosphere, below about $700 \mathrm{hPa}$. Significant dust amounts reach the mid troposphere (about $500 \mathrm{hPa}$ ) but no substantial dust loads reach the upper troposphere, where it would be transported more effectively by the upper tropospheric winds.

It is interesting to note that a similar problem was not found by the application of this dust module to the Sahel/Sahara region (Zakey et al., 2006). In this latter case, most of the vertical transport was achieved through vigorous cumulus convection occurring in the summer monsoon season. In the spring season over East and North Asia, however, convection is not strong and contributes less to vertical transport, which is more related to meso and synoptic scale processes and to detrainment from more stable boundary layers. 


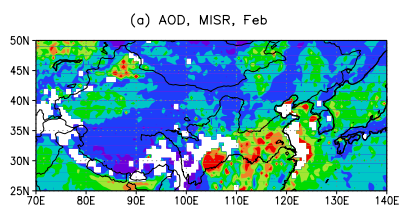

(c) AOD, MISR, Mar

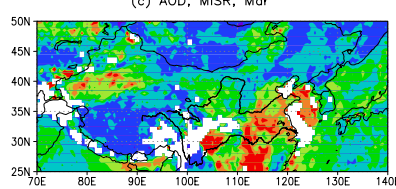

(e) AOD, MISR, Apr

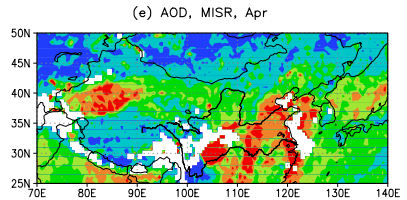

(g) AOD, MISR, May
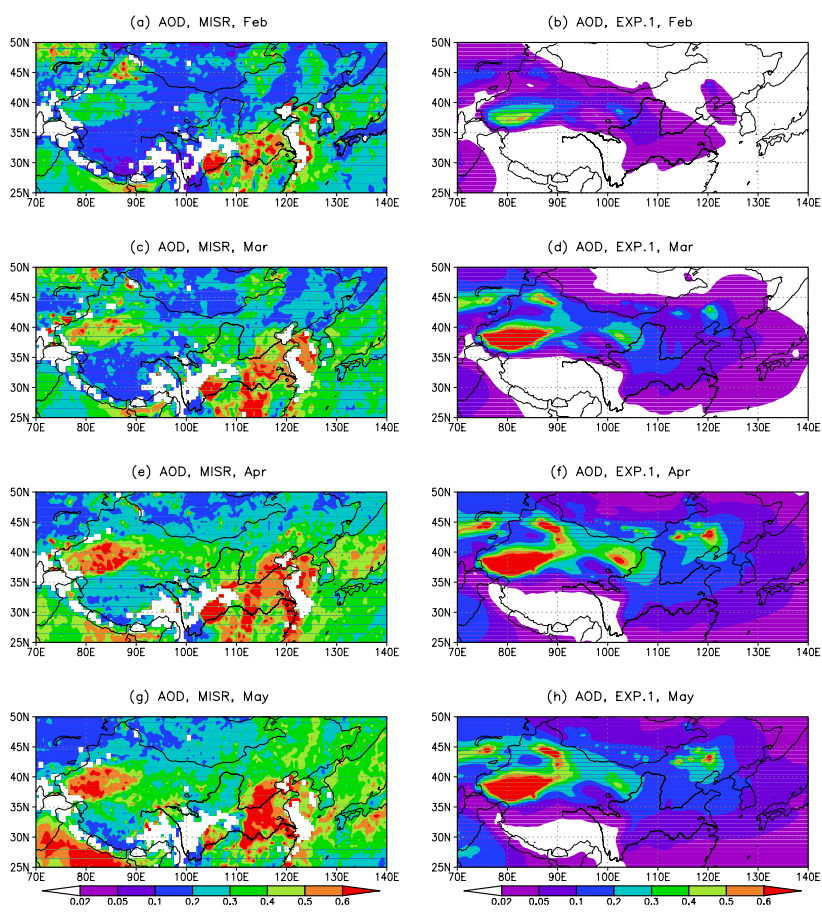

(d) AOD, EXP.1, Mor

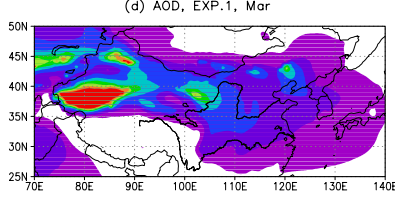

(f) AOD, EXP.1, Ap

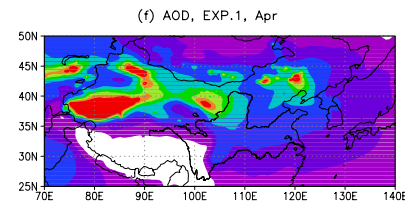

(h) AOD, EXP.1, May

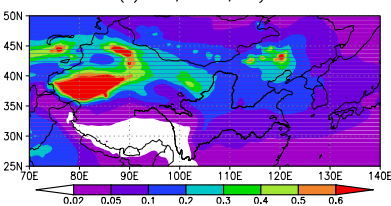

Fig. 6. Observed monthly mean AOD from MISR observations (550 nm) (2001-2006, available data) in (a) February, (c) March, (e) April, (g) May and from the model simulation (Exp. 1 19972006) in (b) February, (d) March, (f) April, (h) May.

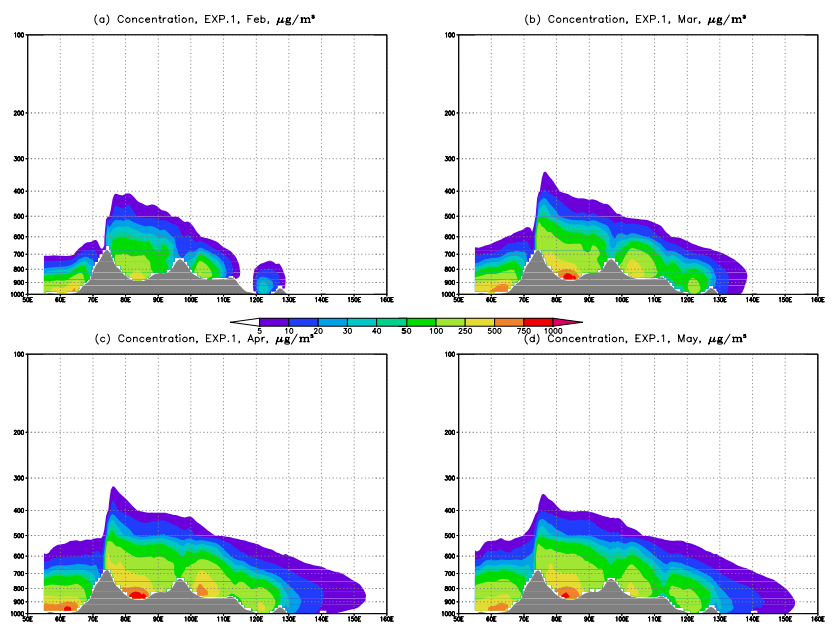

Fig. 7. Simulated (Exp. 1) longitude-height cross section of dust concentration averaged over 1997-2006. (a) February, (b) March, (c) April, (d) May. Units are $\mu \mathrm{g} \mathrm{m}^{-3}$.

Our results suggest that these transport processes are somewhat under-represented by the model. A better understanding of this issue requires vertical dust profile data, which are currently not available. However we plan a more detailed investigation of the structure of individual dust storms and dust lifting in future work.

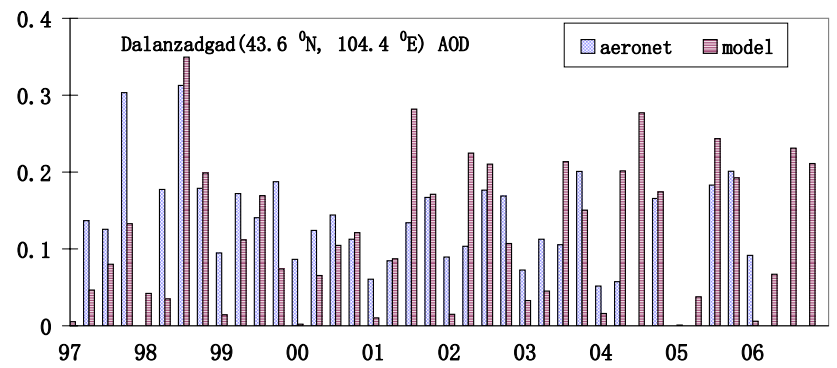

Fig. 8. Monthly mean aerosol optical depth from AERONET observations $(500 \mathrm{~nm})$ and from the model simulation (Exp. 1, 500 nm) at Dalanzadgad.

We also note that over Eastern China the retrieved AOD from satellite is much higher than simulated by the model. However, a dominant contribution to this overestimate is given by the fact that the MISR AOD detects all types of aerosols, including sulfate, black carbon, and organic carbon of anthropogenic origin (Zhao et al., 2006a; Giorgi et al., 2002), which are not included in the current simulations. Note for example the very large AOD (in excess of 0.6) over the Sichuan basin in Southwest China and the Shanghai area in the eastern coastal regions, which is due to intense industrial activities there.

Figure 8 compares our simulated monthly dust aerosol optical depths with observations at the site of Dalanzadgad $\left(43.6^{\circ} \mathrm{N}, 104.4^{\circ} \mathrm{E}\right)$, which is located in the Central region. This is the only AERONET site available in the domain of interest with continuous AOD values for the period of simulation (http://aeronet.gsfc.nasa.gov/cgi-bin/combined_data access_new), and in which the desert dust aerosol can be considered to be largely dominant (Holben et al., 2001). The comparison of simulated vs. AERONET data shows that, although some discrepancies can be found on individual months, by and large the simulated values are in line with observations. In particular, both the intra-seasonal and interannual variations of AOD at this site are well captured.

\subsubsection{Comparison of the simulated dust index (DI) with the aerosol index (AI) from satellite observations}

As mentioned above, for a further model validation we calculate the dust index (DI) following Ginoux et al. (2003) and compare it with the AI derived from the Total Ozone Mapping Spectrometer (TOMS, $380 \mathrm{~nm}, 1997-2005 \mathrm{ftp}: / /$ toms. gsfc.nasa.gov/pub/eptoms/data/), Ozone Monitoring Instrument (OMI, 2006 ftp://toms.gsfc.nasa.gov/pub/omi/data/). Averaged DI and AI for the period 1997-2006 are shown in Fig. 9. The results from this comparison are in line with what found when comparing simulated AOD with the MISR data. The spatial distribution patterns of DI show a good agreement with observations over the main dust source areas. However, the DI is underestimated away from the source 

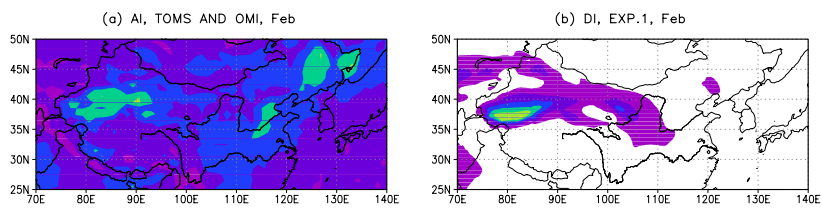

(c) Al, TOMS AND OMI, Mar

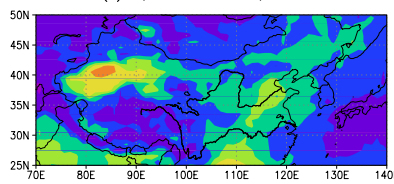

(e) Al, TOMS AND OMI, Apr

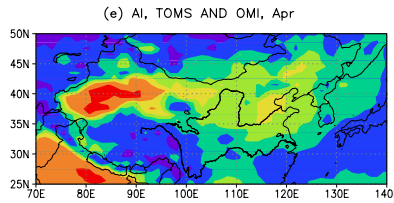

(g) Al, TOMS AND OMI, May
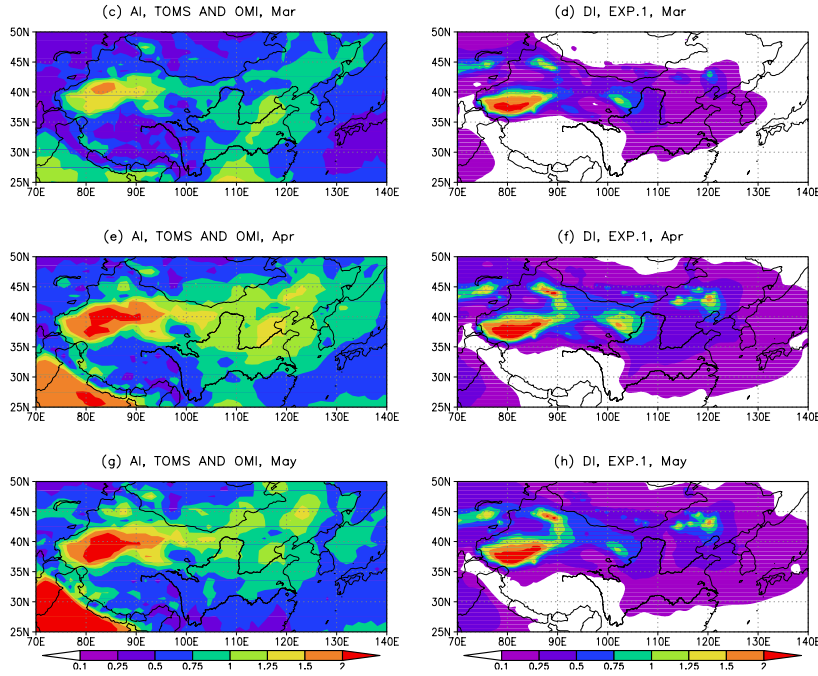

(f) DI, EXP.1, Apr

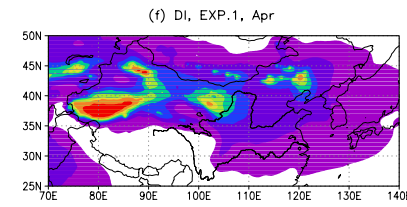

(h) DI, EXP.1, May

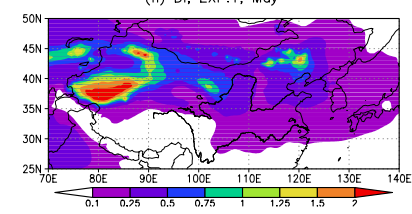

Fig. 9. Observed monthly mean AI from TOMS (1997-2005, available data) and OMI (2006) in (a) February, (c) March, (e) April, (g) May; and simulated (Exp. 1) DI (1997-2006) in (b) February, (d) March, (f) April, (h) May.

regions. As previously discussed, this can be partly attributed to the absence of background and additional aerosols in the model and to relatively weak simulated dust lifting and dispersal. We also find that, again, the intra-seasonal variation of the AI, with the minimum in February and maximum in April, is well captured by the model.

Figure 10 shows the daily AI and DI in the selected regions from February to May for the years 1998 and 2001, i.e. two years when a relatively high number of dust events occurred. The results show that the model captures the occurrence of the main individual dust events, although the magnitude of the event may be different from observed. The correlation coefficients between the daily AI from satellites and the DI from the simulations for each year are presented in Table 3. The mean values of the correlation coefficients are 0.34, 0.37 and 0.36, for the West, East and Central regions, respectively, and are all statistically significant at the $99 \%$ confidence level. In the West region, 7 out of the 10 years show significant correlation, while in the Central and East regions, this is found in 9 and 8 out of the 10 years, respectively (Table 3).

Figure 10 also shows that, while the model captures the occurrence of individual events, sometimes even producing larger values of DI than observed, it underestimates the observed values during the periods that separate the events and more generally it underestimates the amount of background
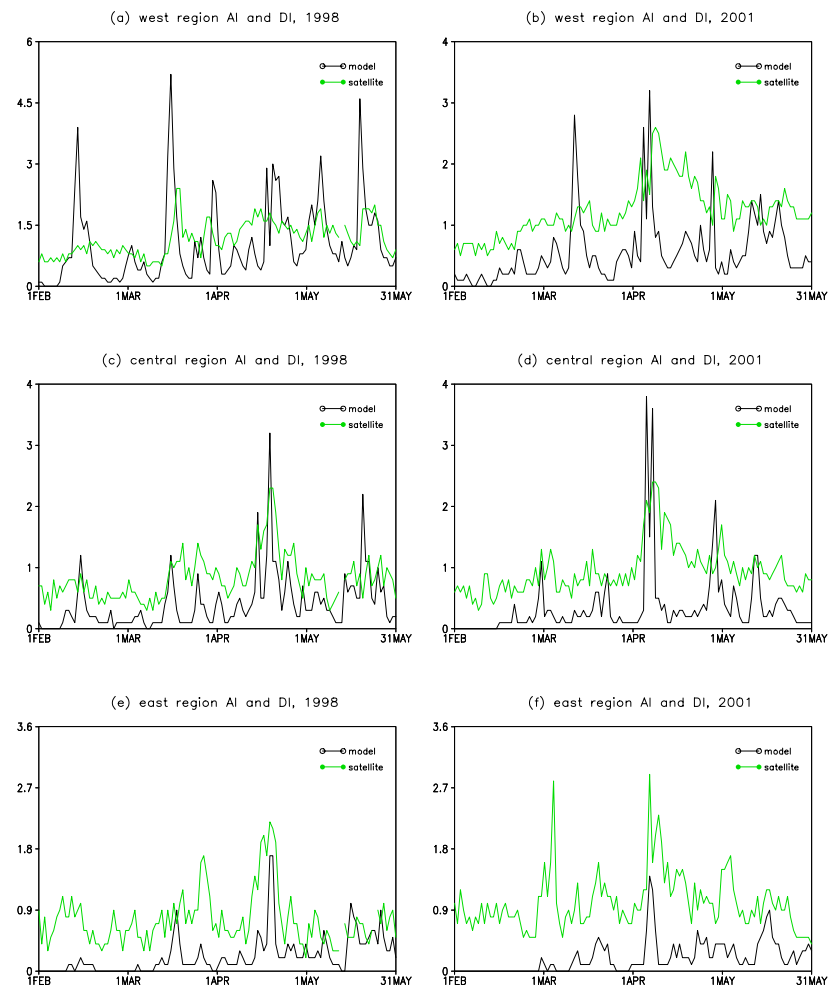

Fig. 10. Daily AI from TOMS and simulated (Exp. 1) DI from February through May over the three source regions in 1998 (a, c, e) and $2001(\mathbf{b}, \mathbf{d}, \mathbf{f})$.

aerosol. Again, this result illustrates the effect of lack of background aerosol and relatively weak dust dispersion in the model discussed above.

\subsection{Observed and simulated dust storm occurrence}

Direct observations of dust storms reported by meteorological stations and synoptic reports have been widely used to establish the climatology of dust emissions in arid and semiarid regions. In Northeastern Asia, Goudie (1983) identified the Taklimakan desert as the most frequent source of dust storms, with 33 dust storms per year, and the northern desert of China as the second source with a maximum of 19 dust storms in the Badain Jaran desert. Figure 11 compares the spatial pattern of observed dust storm occurrences (Zhou et al., 2003) with the model surface concentration above $75 \mu \mathrm{g} \mathrm{m}^{-3}$. The results indicate that the geographical distributions of typical severe dust storms in Northern China are comparable to the surface concentration from the model simulation. It can be seen that the Tarim Basin (West region), the eastern part of Northwest China (Central region) and areas of Northeastern China (East region) are the main regions influenced by severe dust (Zhou et al., 2003).

In order to provide a crude storm count in our model simulations we use three different emission thresholds to 
Table 3. Correlation coefficient between satellite AI and modeled DI in FMAM.

\begin{tabular}{lrcccccccccc}
\hline & 1997 & 1998 & 1999 & 2000 & 2001 & 2002 & 2003 & 2004 & 2005 & 2006 & ave \\
\hline West & 0.22 & $\mathbf{0 . 3 5}$ & 0.16 & $\mathbf{0 . 5 3}$ & $\mathbf{0 . 3 1}$ & $\mathbf{0 . 5 4}$ & $\mathbf{0 . 2 7}$ & $\mathbf{0 . 4 7}$ & $\mathbf{0 . 4 0}$ & 0.22 & $\mathbf{0 . 3 4}$ \\
Central & -0.29 & $\mathbf{0 . 6 3}$ & $\mathbf{0 . 2 7}$ & $\mathbf{0 . 5 4}$ & $\mathbf{0 . 5 6}$ & $\mathbf{0 . 3 4}$ & $\mathbf{0 . 3 7}$ & $\mathbf{0 . 3 2}$ & $\mathbf{0 . 3 6}$ & $\mathbf{0 . 4 1}$ & $\mathbf{0 . 3 7}$ \\
East & -0.08 & $\mathbf{0 . 4 4}$ & 0.14 & $\mathbf{0 . 5 8}$ & $\mathbf{0 . 4 4}$ & $\mathbf{0 . 5 0}$ & $\mathbf{0 . 4 7}$ & $\mathbf{0 . 6 2}$ & $\mathbf{0 . 6 4}$ & $\mathbf{0 . 4 3}$ & $\mathbf{0 . 3 6}$ \\
\hline
\end{tabular}

The bold font indicates correlation coefficient significant at the $99 \%(0.2244)$ confidence level.
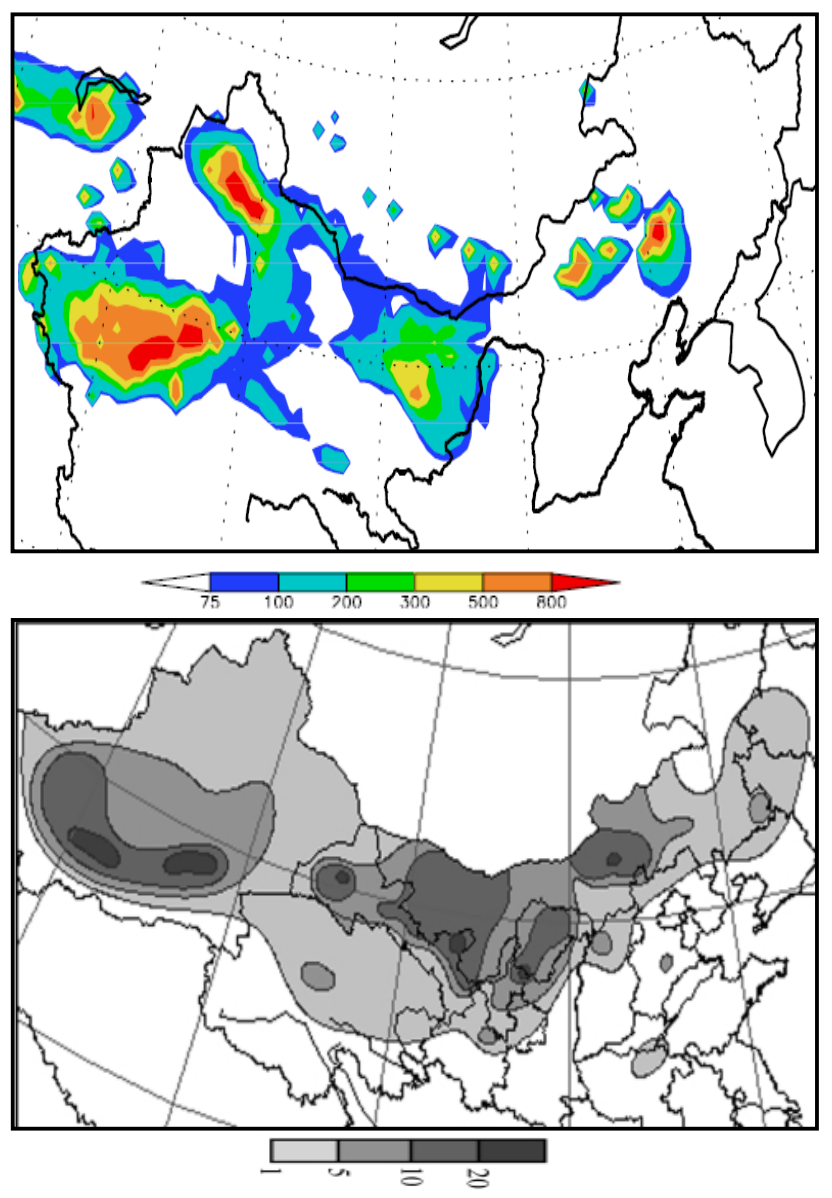

Fig. 11. Distribution of the simulated (Exp. 1) surface concentrations $\left(\mu \mathrm{g} \mathrm{m}^{-3}\right)$ in FMAM from 1997 to 2006 (a) and distribution of the observed typical severe dust storms in Northern China in 19542002 (b).

identify the occurrence of a dust event: 1000, 2500 and $5000 \mathrm{mg} \mathrm{m}^{-2}$ day $^{-1}$. Results of dust occurrence for each year, region and threshold are shown in Fig. 12 and Table 4. According to our emission thresholds, in the model April is the month with the greatest dust storm frequency over all regions (Table 4). For all thresholds the West region emerges with the largest number of storms, in particular with maxima in 1998 and 1999. Over this region the number of occurrences varies from about 46-78 in the lowest threshold to 5-15 in the highest one. Comparatively the East region shows only a small number of dust storm occurrences, while the Central region shows intermediate values.

\subsection{Dust feedbacks on regional climate}

As mentioned, dust, as one of the major natural aerosol in East Asia, can influence the climate of the region by altering the radiative budget of the surface and atmosphere. Dust scatters and partly absorbs incoming solar radiation, and it also absorbs and re-emits outgoing long-wave radiation. Any changes in atmospheric dust loads would cause changes in the radiation balance and, consequently, would affect surface temperatures and other climatic variables. The magnitude and even the sign of the net direct radiative dust forcing for long- and short-wave radiation is highly uncertain, since it depends on the optical properties of the dust, its vertical distribution, cloud cover, and the albedo of the underlying surface (Liao et al., 1998).

The top-of-atmosphere (TOA) forcing due to dust is believed to be small when globally averaged due to the cancellation of regionally positive and negative forcing depending on the underlying albedo. Conversely the reduction of surface radiation by dust is significant even at the global scale, and it has been estimated at $1-2 \mathrm{~W} \mathrm{~m}^{-2}$ (Tegen et al., 1996; Woodward et al., 2001). In order to characterize the climatic impact of dust we compare results from the simulations with and without dust radiative forcing.

Figure 13a-d present the surface and TOA multi-year average dust radiative forcing due to the SW only and the combined SW+LW radiation, respectively. Both the TOA and the surface SW forcing are mostly negative, with values of up to $-7.5 \mathrm{~W} \mathrm{~m}^{-2}$ (TOA) and in excess of $-25 \mathrm{~W} \mathrm{~m}^{-2}$ (surface) over the main source regions. The negative $\mathrm{SW}$ forcing is due to the dominant contribution of reflection in the short-wave spectrum (Shell et al., 2007). When the LW forcing is included (Fig. 13c, d), which is mostly positive due to absorption, the total net radiative forcing becomes less negative, with values of up to $-5 \mathrm{~W} \mathrm{~m}^{-2}$ at the TOA and in excess of $-15 \mathrm{~W} \mathrm{~m}^{-2}$ at the surface. Only over the West source region the LW absorption leads to small positive values at the TOA. Therefore, by and large, the SW cooling effect dominates over the LW warming effect, especially at the surface, which is consistent with the observational study of Slingo et al. (2006). The negative surface radiative forcing causes 

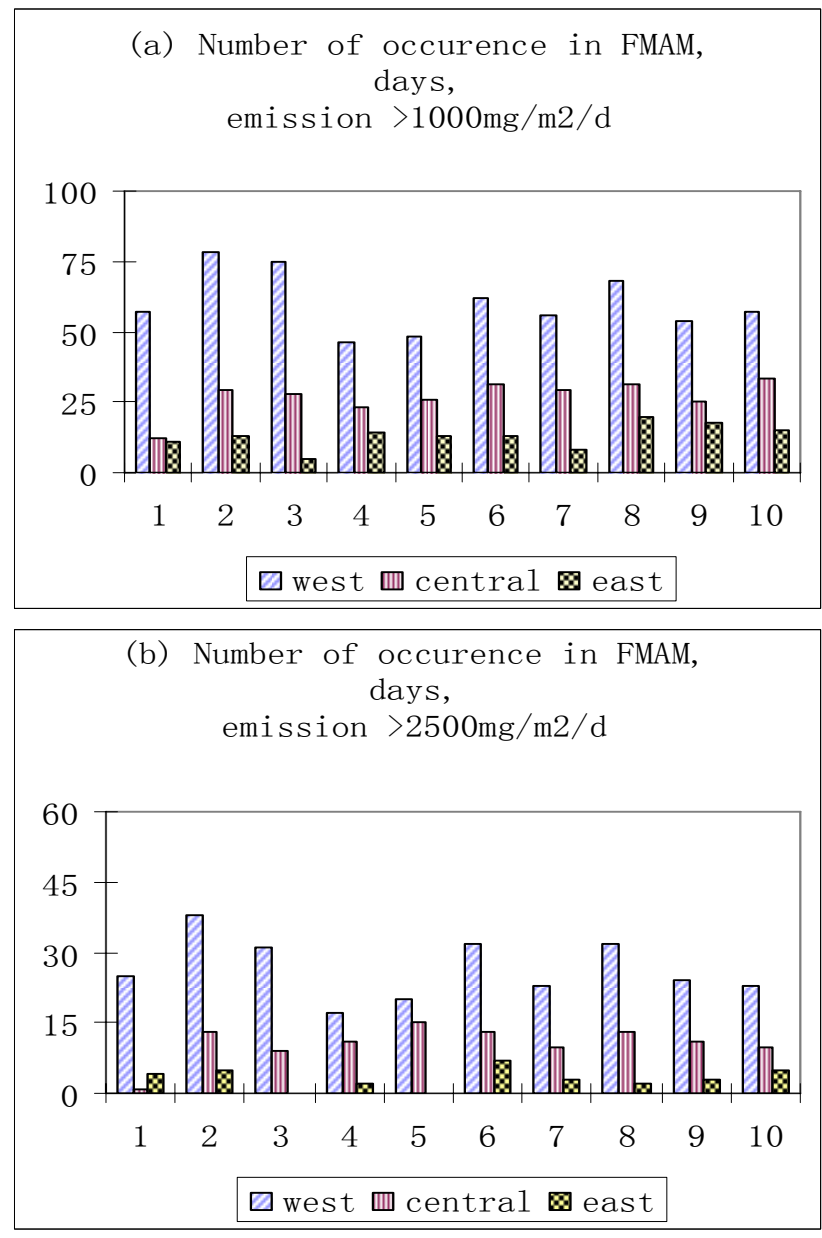

(c) Number of occurence in FMAM, days, emission $>5000 \mathrm{mg} / \mathrm{m} 2 / \mathrm{d}$

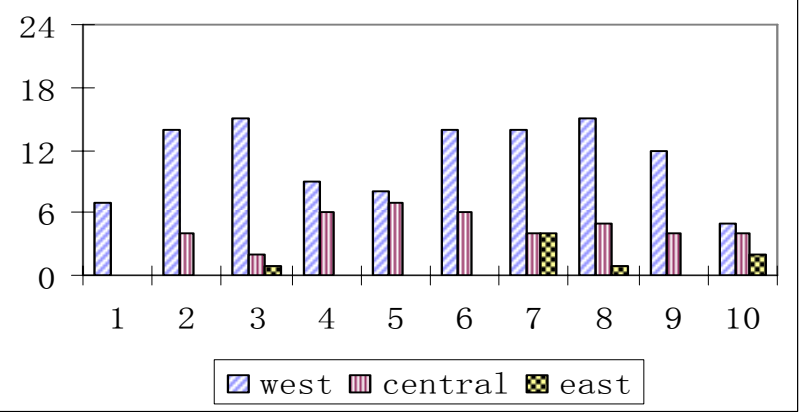

Fig. 12. Number of occurrence (Exp. 1) of dust events in the three source regions of West, Central and East China in FMAM from 1997 to 2006, as defined by the emission thresholds 1000 (a), 2500 (b) and $5000 \mathrm{mg} \mathrm{m}^{-2}$ day $^{-1}$ (c). Units are number of days.

a pronounced reduction of surface fluxes and near surface cooling over the major dust source areas, with values in the range of -0.5 to $-1{ }^{\circ} \mathrm{C}$ (Fig. 13i). This SW cooling counterbalances the LW diabatic warming in the lower troposphere
Table 4. Percentage of occurrence (emission $>1000 / 2500 / 5000 \mathrm{mg}$ $\mathrm{m}^{-2}$ day $^{-1}, \%$ )

\begin{tabular}{lllll}
\hline & February & March & April & May \\
\hline West & $10 / 8 / 4$ & $24 / 23 / 29$ & $31 / 34 / 40$ & $35 / 34 / 27$ \\
Central & $9 / 8 / 5$ & $37 / 34 / 33$ & $39 / 42 / 52$ & $26 / 17 / 10$ \\
East & $2 / 3 / 11$ & $12 / 13 / 11$ & $45 / 52 / 56$ & $42 / 32 / 22$ \\
W+C+E & $8 / 8 / 5$ & $23 / 25 / 29$ & $35 / 38 / 44$ & $34 / 30 / 22$ \\
\hline
\end{tabular}

(Fig. 13h). The cooling in areas downwind of the source regions is less pronounced, but still of the order of -0.1 to $-0.25^{\circ} \mathrm{C}$.

Figure $13 \mathrm{j}$ shows the multi-year mean difference in dust mass load between Exp. 2 (with dust feedbacks) and Exp. 1 (without dust feedbacks). This shows a reduction of dust mass of several hundreds $\mathrm{mg} \mathrm{m}^{-2}$ over the source regions and 10 to $50 \mathrm{mg} \mathrm{m}^{-2}$ over the downwind regions. This result is consistent with those of Perlwitz et al. (2001), who found that dust feedbacks lead to a reduction of about $10 \%$ in dust mass load. To elucidate the mechanisms underlying this feedback, Fig. 14a-f show the change of annual averaged mass load, emission, removal, surface air temperature, wind speed and precipitation respectively, over the three source regions.

A decrease of mass load is found over all the three regions, with a maximum in the West region (Fig. 14a), which is clearly associated with a decrease in emissions (Fig. 14b). The main meteorological factors affecting emission are wind speed and thermal stability (through the friction velocity). Figure $14 \mathrm{e}$ shows that the wind speed is not systematically affected by the dust radiative forcing, therefore the reduction of emission is associated with a reduction of dust mobilization and lifting caused by increased surface stability associated with the surface cooling. In this regard, we note that use of NCEP/NCAR boundary conditions in both sets of experiments might somewhat reduce the response of the simulated winds to the dust forcing. Dust removal also decreases over all regions (Fig. 14c), mostly because of decreased dust amounts, since the dust feedbacks do not produce a large systematic effect on precipitation (only a small decrease, Fig. 14f). The average surface air temperature decreases by $0.20-0.43^{\circ} \mathrm{C}, 0.10-0.17^{\circ} \mathrm{C}, 0.01-0.13^{\circ} \mathrm{C}$ over the West, Central and East regions, respectively (Fig. 14d). Note that these values are comparable to the greenhouse gas induced warming observed in the latest decades of the 20th century (IPCC, 2007).

In summary, the dust feedbacks induces a prevailing negative TOA and surface radiative forcing, which in turn causes surface cooling, a decrease of dust mobilization over the source areas and a reduction of dust mass load. 
(a) TOArad SW Forcing, EXP.1, FMAM, $\mathrm{W} \mathrm{m}^{-2}$

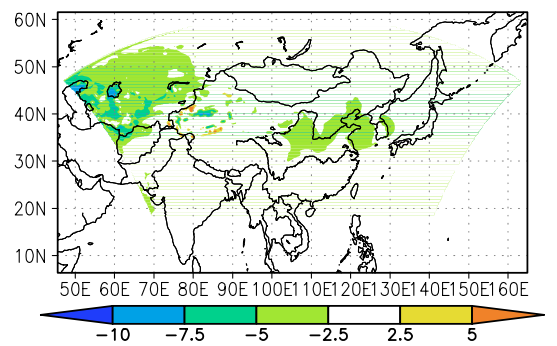

(c) TOArad LW+SW Forcing, EXP.1, FMAM, W $\mathrm{m}^{-2}$

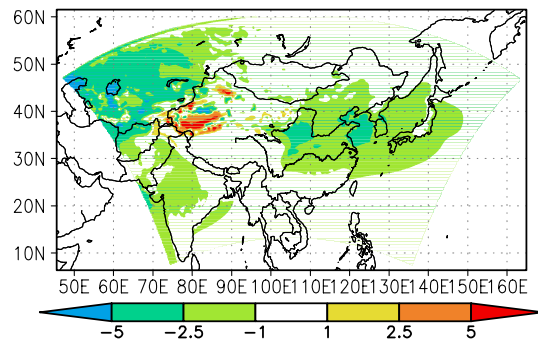

(e) Solar Heating Rate, EXP.2-EXP.1, FMAM, $\mathrm{K} \mathrm{s}^{-1}$

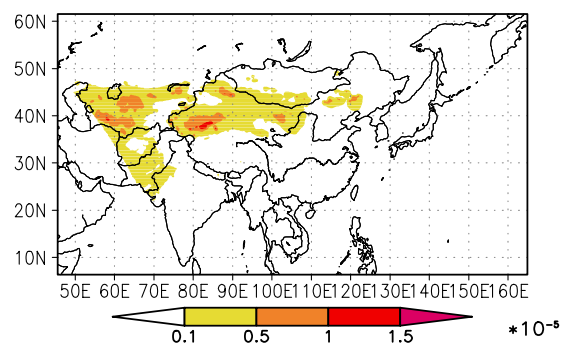

(g) Downward Longwave, EXP.2-EXP.1, FMAM, W m ${ }^{-2}$

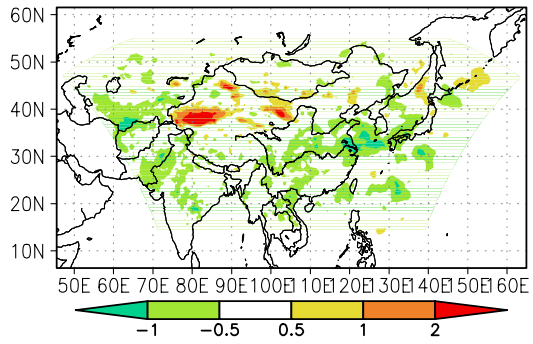

(i) Temperature, EXP.2-EXP.1, FMAM, ${ }^{\circ} \mathrm{C}$

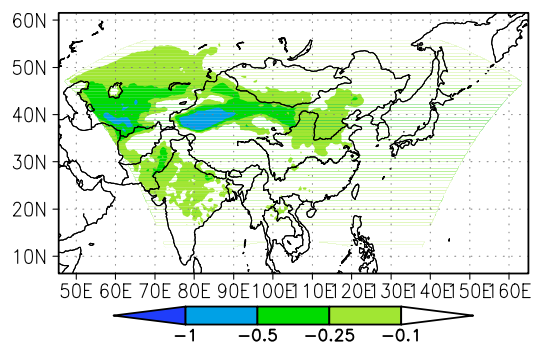

(b) SRFrad SW Forcing, EXP.1, FMAM, $\mathrm{W} \mathrm{m}^{-2}$

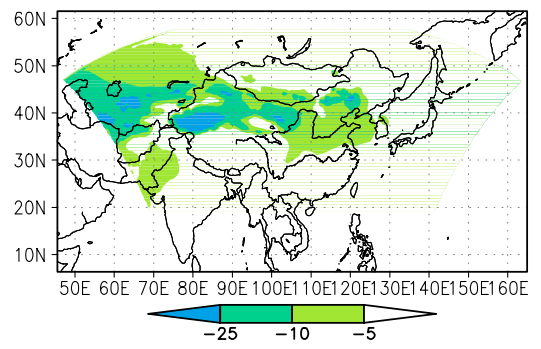

(d) SRFrad LW+SW Forcing, EXP.1, FMAM, W $\mathrm{m}^{-2}$

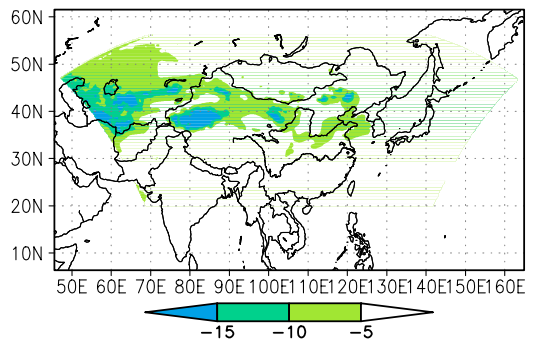

(f) Longwave Heating Rate, EXP.2-EXP.1, FMAM, $\mathrm{K} \mathrm{s}^{-1}$

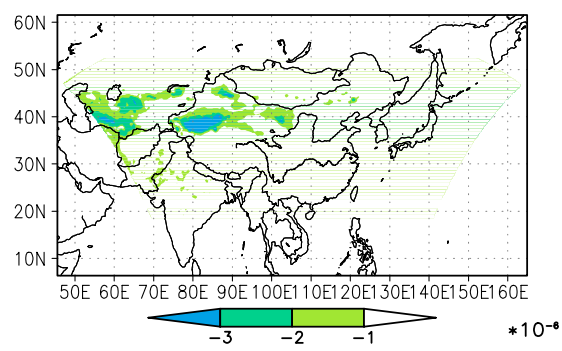

(h) Net Longwave, EXP.2-EXP.1, FMAM, $\mathrm{W} \mathrm{m}^{-2}$

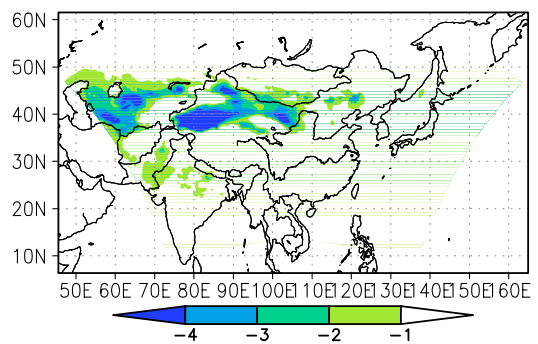

(j) Mass load, EXP.2-EXP.1, FMAM, $\mathrm{mg} \mathrm{m}^{-2}$

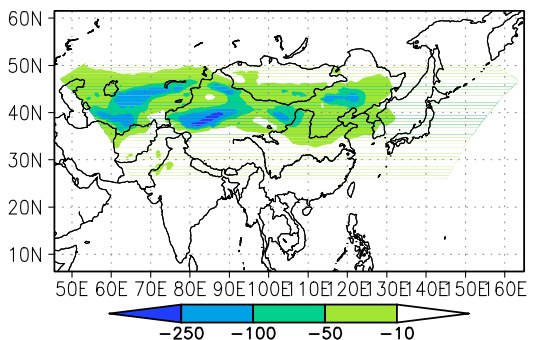

Fig. 13. Dust feedback effects. (a) dust $\mathrm{SW}$ TOA radiative forcing $\left(\mathrm{W} \mathrm{m}^{-2}\right)$, (b) dust $\mathrm{SW}$ surface radiative forcing $\left(\mathrm{W} \mathrm{m}^{-2}\right)$, (c) dust net TOA radiative forcing $\left(\mathrm{W} \mathrm{m}^{-2}\right)$, (d) dust net surface radiative forcing $\left(\mathrm{W} \mathrm{m}^{-2}\right)$, (e) solar heating rate $\left(\mathrm{W} \mathrm{m}^{-2}\right)$, (f) long-wave heating rate $\left(\mathrm{W} \mathrm{m}^{-2}\right),(\mathbf{g})$ downward long-wave solar radiation $\left(\mathrm{W} \mathrm{m}^{-2}\right),(\mathbf{h})$ net long-wave solar radiation $\left(\mathrm{W} \mathrm{m}^{-2}\right),(\mathbf{i})$ surface air temperature $\left({ }^{\circ} \mathrm{C}\right),(\mathbf{j})$ dust mass load $\left(\mathrm{mg} \mathrm{m}^{-2}\right)$. 


\section{Summary and conclusions}

In this paper we use a coupled regional climate-dust model, the only currently available in the literature, to simulate desert dust production and regional climatic effects over East Asia. We analyze the simulation of ten spring seasons (i.e. the season of maximum dust production over the region) and evaluate the model performance against available observations, both ground based and from satellite. Finally, we assess the net short- and long-wave radiative forcing and feedbacks of the dust aerosols over the region.

The results show that the model reproduces the basic climatology over the region and that the dust model performs reasonably well in simulating the spatial distribution, intraseasonal variation and multi-year mean monthly variation of near surface concentration, AOD, and DI. The primary model deficiency is an overestimate of dust load and AOD over the source regions and a corresponding underestimate away from these regions. This problem is symptomatic of relatively weak lifting of dust into the free troposphere and weak dispersal, although a contribution to it is given by the absence in the model of background and additional aerosols. In future work we plan to investigate in more detail the dynamical mechanisms that lead to dust lifting and improve the model performance in this respect. Another aspect in need of further investigation concerns the aerosol optical properties in both the SW and LW spectra, which are still affected by large uncertainties (e.g. Balkanski et al., 2007).

The dust exerts a negative radiative forcing in the SW and a positive forcing in the $\mathrm{LW}$, which somewhat counterbalance each other. However the SW forcing is largely dominant, resulting in a negative net radiative forcing at the surface of up to $-15 \mathrm{~W} \mathrm{~m}^{-2}$ over the source regions and a prevailing negative TOA forcing of up to a few $\mathrm{W} \mathrm{m}^{-2}$. The only exception of a positive TOA forcing is over some portions of the West source region.

The negative surface radiative forcing leads to a surface cooling of several tenths of ${ }^{\circ} \mathrm{C}$ to $1^{\circ} \mathrm{C}$ over the source regions and downwind areas. The surface cooling causes a decrease of dust load because of increased stability and reduced dust mobilization. As a result, the net TOA dust radiative forcing induces a negative feedback mechanism on the dust load. The effects of dust on regional temperatures are locally comparable to those expected from increases of greenhouse gas concentrations during the last decades, which suggests that dust should be included in climate change studies over this region.

Our study is limited in two aspects. Firstly, we do not include the contribution of other aerosols, e.g. sulfate, black carbon and organic carbon, which have been proven to be important over East Asia (Giorgi et al., 2002). This is because in this study we wanted to isolate the effects of dust. However, our modeling system has the capability of including such additional aerosols (Solmon et al., 2006), so that we plan to perform new sets of simulations including all aerosol
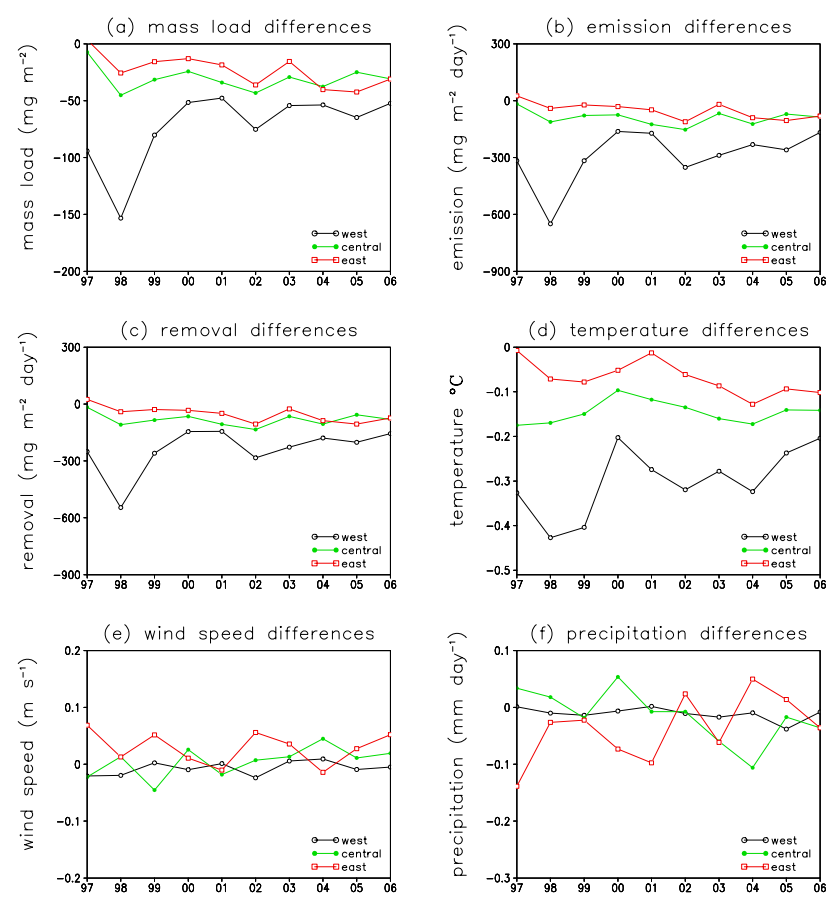

Fig. 14. Differences between Exp. 1 and Exp. 2 over the three source regions of (a) mass load $\left(\mathrm{mg} \mathrm{m}^{-2}\right)$, (b) dust emission $\left(\mathrm{mg} \mathrm{m}^{-2} \mathrm{day}^{-1}\right)$, (c) dust removal $\left(\mathrm{mg} \mathrm{m}^{-2} \mathrm{day}^{-1}\right)$, (d) surface air temperature $\left({ }^{\circ} \mathrm{C}\right),(\mathbf{e})$ wind speed $\left(\mathrm{m} \mathrm{s}^{-1}\right)$, and (f) precipitation mm day ${ }^{-1}$.

types. Secondly, indirect effects, e.g. the role of dust particles as cloud condensation nuclei, are not described in our simulation and we are currently implementing in our model a new cloud microphysics and indirect effect scheme. Eventually we plan to use the full model with multiple aerosols and direct and indirect effects for a new set of climate change simulations over East Asia.

Acknowledgements. This research is jointly supported by the National Key Program for Developing Basic Sciences (2006CB403700, 2006CB400506) of China and Climate Change Study Fund of the China Meteorological Administration. The authors would like to thank P. Yan and two anonymous reviewers for their valuable discussions and comments on this work.

Edited by: Y. Balkanski

\section{References}

Alfaro, S. C. and Gomes, L.: Modelling mineral aerosol production by wind erosion: Emission intensities and aerosol size distributions in source areas, J. Geophys. Res., 106(D16), 18075-18084, 2001.

Aoki, T., Tanaka, T. Y., Uchiyama, A., Chiba, M., Mikami, M., and Key, J. R.: Sensitivity experiments of direct radiative forcing by 
mineral dust using spectrally detailed radiative transfer model, J. Meteorol. Soc. Jpn., 83A, 315-331, 2005.

Balkanski, Y., Schulz, M., Claquin, T., and Guibert, S.: Reevaluation of Mineral aerosol radiative forcings suggests a better agreement with satellite and AERONET data, Atmos. Chem. Phys., 7, 81-95, 2007, http://www.atmos-chem-phys.net/7/81/2007/.

Biscaye, P. E., Grousset, F. E., Revel, M., der Gaast, S. V., Zielinski, G. A., Vaars, A., and Kukla, G.: Asian provenance of glacial dust (stage 2) in the Greenland Ice Sheet Project 2 Ice Core, Summit, Greenland, J. Geophys. Res., 102(C12), 26765-26781, 1997.

Bory, A. J. M., Biscaye, P. E., and Grousset, F. E.: Two distinct seasonal Asian source regions for mineral dust deposited in Greenland (NorthGRIP), Geophys. Res. Lett., 30(4), 1167, doi:10.1029/2002GL016446, 2003.

Cheng, L. S. and Ma, Y.: The developing structure of a black storm and its numerical experiment of different model resolution, Quarter J. Appl. Meteor., 7, 386-395, 1996 (in Chinese).

Christopher, S. A., Wang, J., Ji, Q., and Tsay, S.: Estimation of diurnal shortwave dust aerosol radiative forcing during PRIDE, J. Geophys. Res., 108(D19), 8596, doi:10.1029/2002JD002787, 2003.

Chun, Y. S., Boo, K. O., Kim, J., Park, S., and Lee, M.: Synopsis, transport and physical characteristics of Asian dust in Korea, J. Geophys. Res., 106(D16), 18461-18469, 2001.

Dentener, F. J., Carmichael, G. R., Zhang, Y., Lelieveld, J., and Crutzen, P. J.: Role of mineral dust aerosol as a reactive surface in the global troposphere, J. Geophys. Res., 101(D17), 2286922889, 1996.

Dey, S., Tripathi, S. N., Singh, R. P., and Holben, B. N.: Influence of dust storms on the aerosol optical properties over the Indo-Gangetic basin, J. Geophys. Res., 109, D20211, doi:10.1029/2004JD004924, 2004.

Dickinson, R., Henderson-Sellers, A., and Kennedy, P.: Biosphereatmosphere transfer scheme (bats) version 1e as coupled to the NCAR community climate model, Technical report, National Center for Atmos. Res., 72 pp., 1993.

Dickerson, R. R., Kondragunta, S., Stenchikov, G., Civerolo, K. L., Doddridge, B. G., and Holben, B.: The impact of aerosols on solar UV radiation and photochemical smog, Science, 278, 827830, 1997.

Gillette D. A. and Hanson, K. J.: Spatial and temporal variability of dust production caused by wind erosion in the United States, J. Geophys. Res., 94(D2), 2197-2206, 1989.

Ginoux, P. and Torres, O.: Empirical TOMS index for dust aerosol: Applications to model validation and source characterization, J. Geophys. Res., 108(D17), 4534, doi:10.1029/2003JD003470, 2003.

Ginoux, P., Prospero, J., Torres, O., and Chin, M.: Long-term simulation of dust distribution with the GOCART model: Correlation with the North Atlantic Oscillation, Environ. Model. Softw., 19, 113-128, 2004.

Giorgi, F. and Chameides, W. L.: Rainout lifetimes of highly soluble aerosols and gases as inferred from simulations with a general circulation model, J. Geophys. Res., 91(D13), 14367-14376, 1986.

Giorgi, F.: Two-dimensional simulations of possible mesoscale effects of nuclear war fires, I: Model description, J. Geophys. Res., 94(D1), 1127-1144, 1989.

Giorgi, F., Marinucci, M., and Bates, G.: Development of a second generation regional climate model (RegCM2), Part I: Boundary layer and radiative transfer processes, Mon. Weather Rev., 121, 2794-2813, 1993a.

Giorgi, F., Marinucci, M., Bates, G., and DeCanio, G.: Development of a second generation regional climate model (RegCM2), Part II: Convective processes and assimilation of lateral boundary conditions, Mon. Weather Rev., 121, 2814-2832, 1993b.

Giorgi, F. and Bi, X. Q.: Direct radiative forcing and regional climatic effects of anthropogenic aerosols over East Asia: A regional coupled climate-chemistry/aerosol model study, J. Geophys. Res., 107(D20), 4439, doi:10.1029/2001JD001066, 2002.

Gong, S. L., Zhang, X. Y., Zhao, T. L., McKendry, I. G., Jaffe, D. A., and Lu, N. M.: Characterization of soil dust aerosol in China and its transport and distribution during 2001 ACE-Asia: 2. Model simulation and validation, J. Geophys. Res., 108(D9), 4262, doi:10.1029/2002JD002633, 2003.

Goudie, A. S.: Dust storms in space and time, Prog. Phys. Geog., 7(4), 502-530, 1983.

Goudie, A. S. and Middleton, N. J.: The changing frequency of dust storms through time, Climatic Change, 20, 197-225, 1992.

Grousset, F. E., Ginoux, P., Bory, A., and Biscaye, P. E.: Case study of a Chinese dust plume reaching the French Alps, Geophys. Res. Lett., 30(6), 1277, doi:10.1029/2002GL016833, 2003.

Grell, G. A.: Prognostic evaluation of assumptions used by cumulus parameterizations, Mon. Weather Rev., 121, 764-787, 1993.

Hess, M., Kopke, P., and Schult, I.: Optical properties of aerosols and clouds: The software package OPAC, B. Am. Meteorol. Soc., 79, 831-844, 1998.

Holben, B. N., Tanre, D., Smirnov, A., Eck, T. F., Slutsker, I., Abuhassan, N., Newcomb, W. W., Schafer, J., Chatenet, B., Lavenue, F., Kaufman, Y. J., Vande Castle, J., Setzer, A., Markham, B., Clark, D., Frouin, R., Halthore, R., Karnieli, A., O’Neill, N. T., Pietras, C., Pinker, R. T., Voss, K., and Zibordi, G.: An emerging ground-based aerosol climatology: Aerosol optical depth from AERONET, J. Geophys. Res., 106(D11), 1206712097, 2001.

Holtslag, A., de Bruijn, E., and Pan, H. L.: A high resolution air mass transformation model for short-range weather forecasting, Mon. Weather Rev., 118, 1561-1575, 1990.

Hou, X. Y.: Vegetation map of China (1:4000000), Cartographic Publishing House, Beijing, China, 1982.

Hsu, S. A.: Thermodynamic characteristics of the subcloud layer affecting haze dispersion along the West coast of Borneo, Pure Appl. Geophys., 160, 419-427, 2003.

Husar, R. B., Tratt, D. M., Schichtel, B. A., Falke, S. R., Li, F., Jaffe, D., Gasso, S., Gill, T., Laulainen, N. S., Lu, F., Reheis, M. C., Chun, Y., Westphal, D., Holben, B. N., Gueymard, C., McKendry, I., Kuring, N., Feldman, G. C., McClain, C., Frouin, R. J., Merrill, J., DuBois, D., Vignola, F., Murayama, T., Nickovic, S., Wilson, W. E., Sassen, K., Sugimoto, N., and Malm, W. C.: Asian dust event of April 1998, J. Geophys. Res., 106(D16), 18317-18330, 2001.

Intergovernmental Panel on Climate Change (IPCC), Climate Change 2007: The Physical Science Basis, in: Contribution of WGI to the IPCC AR4, edited by: Solomon, S., Qin, D., Manning, M., Chen, Z., Marquis, M., Averyt, K. B., Tignor, M., and Miller, H. L., Cambridge University Press, Cambridge, UK and New York, NY, USA, 2007.

Joussaume, S.: Three-dimensional simulation of the atmospheric 
cycle of desert dust particles using a general circulation model, J. Geophys. Res., 95(D2), 1909-1941, 1990.

Kalnay E., Kanamitsua, M., Kistlera, R., et al.: The NCEP/NCAR 40-Year Reanalysis Project, B. Am. Meteorol. Soc., 77, 437-471, 1996.

Kiehl, J., Hack, J., Bonan, G., Boville, B., Breigleb, B., Williamson, D., and Rasch, P.: Description of the NCAR community climate model (ccm3), Technical report, National Center for Atmos. Res., 152 pp., 1996.

Kurosaki, Y. and Mikami, M.: Recent frequent dust events and their relation to surface wind in East Asia, Geophys. Res. Lett., 30(14), 1736, doi:10.1029/2003GL017261, 2003.

Liao, H. and Seinfeld, J. H.: Radiative forcing by mineral dust aerosols: sensitivity to key variables, J. Geophys. Res., 103(D24), 31637-31646, 1998.

Liu, M., Westphal, D. L., Wang, S., Shimizu, A., Sugimoto, N., Zhou, J., and Chen, Y.: A highresolution numerical study of the Asian dust storms on April 2001, J. Geophys. Res., 108(D23), 8653, doi:10.1029/2002JD003178, 2003.

Loveland, T. R., Reed, B. C., Brown, J. F., Ohlen, D. O., Zhu, J, Yang, L., and Merchant, J. W.: Development of a global land cover characteristics database and IGBP DISCover from $1-\mathrm{km}$ AVHRR data, Int. J. Remote Sens., 21(6-7), 1303-1330, 2000.

Luo, C., Mahowald, N., and del Corral, J.: Sensitivity study of meteorological parameters on mineral aerosol mobilization, transport and distribution, J. Geophys. Res., 108(D15), 4447, doi:10.1029/2002JD003483, 2003.

Marticorena, B. and Bergametti, G.: Modeling the atmospheric dust cycle, I, Design of soil-soilderived dust emission scheme, J. Geophys. Res., 100(D8), 16415-16430, 1995.

Martin, R. V., Jacob, D. J., Yantosca, R. M., Chin, M., and Ginoux, P.: Global and regional decreases in tropospheric oxidants from photochemical effects of aerosols, J. Geophys. Res., 108(D3), 4097, doi:10.1029/2002JD002622, 2003.

McKendry, I. G., Hacker, J. P., Stull, R., Sakiyama, S., Mignacca, D., and Reid, K.: Long-range transport of Asian dust to the Lower Fraser Valley, British Columbia, Canada, J. Geophys. Res., 106(D16), 18361-18370, 2001.

Myhre, G. and Stordal, F.: Global sensitivity experiments of the radiative forcing due to mineral aerosols, J. Geophys. Res., 106(D16), 18193-18204, 2001.

Mitchell, T. D. and Jones., P. D.: An improved method of constructing a database of monthly climate observations and associated high-resolution grids, Int. J. Climatol., 25, 693-712, 2005.

Natsagdorj, L., Jugder, D., and Chung, Y. S.: Analysis of dust storms observed in Mongolia during 1937-1999, Atmos. Environ., 37, 1401-1411, 2003.

Nickovic, S., George, K., Anastasios, P., and Olga, K.: A model for prediction of desert dust cycle in the atmosphere, J. Geophys. Res., 106(D16), 18113-18129, 2001.

Pal, J. S., Small, E. E. and Eltahir, E. A. B.: Simulation of regionalscalewater and energy budgets: Representation of subgrid cloud and precipitation processes within RegCM, J. Geophys. Res., 105(D24), 29579-29594, 2000.

Pal, J. S., Giorgi, F., Bi, X., Elguindi, N., Solmon, F., Gao, X., Rauscher, S. A., Francisco, R., Zakey, A., Winter, J., Ashfaq, M., Syed, F. S., Bell, J. L., Diffenbaugh, N. S., Karmacharya, J., Konare, A., Martinez, D., da Rocha, R. P., Sloan, L. C., and Steiner, A.: Regional climate modeling for the developing world: The ICTP RegCM3 and RegCNET, B. Am. Meteorol. Soc., 88(9), 1395-1409, 2007.

Perlwitz, J., Tegen, I., and Miller, R. L.: Interactive soil dust aerosol model in the GISS GCM: 1 . Sensitivity of the soil dust cycle to radiative properties of soil dust aerosols, J. Geophys. Res. 106(D16), 18167-18192, 2001.

Porter, S. C.: Chinese loess record of monsoon climate during the last glacial-interglacial cycle, Earth Sci. Rev., 54, 115-128, 2001.

Prospero, J. M., Ginoux, P., Torres, O., Nicholson, S. E., and Gill, T. E.: Environmental characterization of global sources of atmospheric soil dust identified with the NIMBUS 7 Total Ozone Mapping Spectrometer (TOMS) absorbing aerosol product, Rev. Geophys., 40, 2-31, 2002.

Pye, K.: Aeolian Dust and Dust Deposits, Academic Press, London, 334 pp., 1987.

Qin, D. H.: Assessment for evolution of environment in Western China, Science Press, Beijing, China, 80 pp., 2002 (in Chinese).

Rao, S. T., Ku, J. Y., Berman, S., Zhang, K., and Mao, H.: Summertime characteristics of the atmospheric boundary layer and relationships to ozone levels over the Eastern United States, Pure Appl. Geophys., 160, 21-55, 2003.

Shao, Y. and Leslie, L. M.: Wind erosion prediction over the Australian continent, J. Geophys. Res., 102, D25, 30091-30105, 1997.

Shao, Y. and Wang, J. J.: A climatology of northeast Asian dust events, Meteorol. Z., 12, 175-183, 2003.

Shao, Y. and Dong, C.: A review on East Asian dust storm climate, modelling and monitoring, Global Planet. Change, 52, 122, doi:10.1016/j.gloplacha.2006.02.011, 2006.

Shell, K. M. and Someville, R. C. J.: Direct radiative effect of mineral dust and volcanic aerosols in a simple aerosol climate model, J. Geophys. Res., 112, D03205, doi:10.1029/2006JD007197, 2007.

Slingo, A., Ackerman, T. P., Allan, R. P., Kassianov, E. I., McFarlane, S. A., Robinson, G. J., Barnard, J. C., Miller, M. A., Harries, J. E., and Russell, J. E.,: Observations of the impact of a major Saharan dust storm on the atmospheric radiation balance, Geophys. Res. Lett., 33, L24817, doi:10.1029/2006GL027869, 2006.

Sokolik, I. N. and Toon, O. B.: Direct radiative forcing by anthropogenic airborne mineral aerosols, Nature, 381, 681-683, 1996.

Solmon, F., Giorgi, F., and Liousse, C.: Aerosol modeling for regional climate studies: Application to anthropogenic particles and evaluation over a European/African domain, Tellus B, 58(1), 51-72, 2006.

Tanaka, T. Y., Orito, K., Sekiyama, T. T., Shibata, K., Chiba, M., and Tanaka, H.: MASINGAR, a global tropospheric aerosol chemical transport model coupled with MRI/JMA98 GCM: model description, Pap. Meteorol. Geophys., 53, 119-138, 2003.

Tegen, I. and Fung, I.: Modeling of mineral dust in the atmosphere: sources, transport, and optical thickness, J. Geophys Res., 99(D11), 22897-22914, 1994.

Tegen, I. and Lacis, A. A.: Modeling of particle size distribution and its influence on the radiative properties of mineral dust aerosol, J. Geophys. Res., 101(D14), 19237-19244, 1996.

Tegen, I., Harrison, S. P., Kohfeld, K., Prentice, I. C., Coe, M., and Heimann, M.: Impact of vegetation and preferential source areas on global dust aerosol: results from a model study, J. Geophys. Res., 107(D21), 4576, doi:10.1029/2001JD000963, 2002. 
USDA: Soil Taxonomy, a basic system of Soil Classification for making and interpreting Soil Surveys, US Government Printing Office, Washington, USA, 869 pp., 1999.

ang, H., Shi, G. Y., Li, S. Y., Li, W., Wang, B., and Huang, Y. B.: The impacts of optical properties on radiative forcing due to dust aerosol, Adv. Atmos. Sci., 23(3), 431-441, 2006.

Westphal, D. L., Toon, O. B., and Carson, T. N.: A case study of mobilisation and transport of Saharan dust, J. Atmos. Sci., 45, 2145-2175, 1988.

Woodward, S.: Modeling the atmospheric lifecycle and radiative impact of mineral dust in the Hadley Centre climate model, J. Geophys. Res., 106(D16), 18155-18166, 2001.

Zakey, A. S., Solmon, F., and Giorgi, F.: Implementation and testing of a desert dust module in a regional climate model, Atmos. Chem. Phys., 6, 4687-4704, 2006,

http://www.atmos-chem-phys.net/6/4687/2006/.

Zender, C. S., Bian, H., and Newman, D.: Mineral Dust Entrainment and Deposition (DEAD) model: description and 1990s dust climatology, J. Geophys. Res., 108(D14), 4416, doi:10.1029/2002JD002775, 2003.

Zender, C. S., Miller, R. L., and Tegen, I.: Quantifying mineral dust mass budgets: Terminology, constraints, and current estimates, Eos Trans. Am. Geophys. Union, 85(48), 509-512, 2004.

Zhang, D. E.: Synoptic-climatic studies of dust fall in China since historic times, Sci. Sinica., Ser. B, Chem. Biol. Agric. Med. Earth Sci., 27, 825-836, 1984.

Zhang, D. F., Ouyang, L. C., Gao, X. J., Giorgi, F., and Pal, J. S.: Simulation of the atomospheric circulation over East Asia and climate in China by RegCM3, J. Tropical Meteor., 23(5), 444452, 2007 (in Chinese).
Zhang, J. and Christopher, S. A.: Longwave radiative forcing of Saharan dust aerosols estimated from MODIS, MISR, and CERES observation on Terra, Geophys. Res. Lett., 30(23), 2188, doi:10.1029/2003GL018479, 2003.

Zhang, R. J., Han, Z. W., Wang, M. X., and Zhang, X. Y.: Dust storm weather in China: new characteristics and origins, Quat. Sci., 22(4), 374-380, 2002 (in Chinese).

Zhang, X. Y.: Source distributions, emission, transport, deposition of Asian dust and Loess accumulation, Quat. Sci., 21, 29-38, 2001.

Zhang, X. Y., Gong, S. L., Zhao, T. L., Arimoto, R., Wang, Y. Q., and Zhou, Z. J.: Sources of Asian dust and role of climate change versus desertification in Asian dust emission, Geophys. Res. Lett., 30(24), 2272, doi:10.1029/2003GL018206, 2003a.

Zhang, X. Y., Gong, S. L., Arimoto, R., Shen, Z. X., Mei, F. M., Wang, D., and Cheng, Y.: Characterization and temporal variation of Asian dust aerosol from a site in the northern Chinese deserts, J. Atmos. Chem., 44, 241-257, 2003 b.

Zhao, C. S., Tie, X. X., and Lin, Y. P.: A possible positive feedback of reduction of precipitation and increase in aerosols over eastern China, Geophys. Res. Lett., 33, L11814, doi:10.1029/2006GL025959, 2006a.

Zhao, L. N. and Zhao, S. X.: Diagnosis and simulation of a rapidly developing cyclone related to a severe dust storm in East Asia, Global Planet. Change, 52, 105-120, doi:10.1016/j.gloplacha.2006.02.003, 2006b.

Zhou, Z. J.: Blowing sand and sand storm in China in recent 45 years, Quat. Sci., 21, 9-17, 2001.

Zhou, Z. J. and Zhang, G. C.: Typical severe dust storms in northern China during 1954-2002, Chinese Sci. Bull., 48(21), 2366-2370, 2003. 